\title{
INKONSISTENSI PUTUSAN MAHKAMAH KONSTITUSI TERHADAP KEBERADAAN KOMISI PEMBERANTASAN KORUPSI SEBAGAI LEMBAGA NEGARA INDEPENDEN
}

\author{
Theresa Yolanda Sirait ${ }^{1}$, Bintang ME Naibaho², Janpatar Simamora ${ }^{3}$, \\ Leonardo David Simatupang ${ }^{4}$ \\ Program Studi Ilmu Hukum dan Magister Hukum \\ Universitas HKBP Nommensen, Medan-Sumatera Utara-Indonesia \\ e-mail: theresayolandaas@gmail.com
}

\begin{abstract}
The Constitutional Court as mandated in the constitution has a function as a guardian of the constitution, therefore, if there are norms in the Act that against to the 1945 Constitution of the Republic of Indonesia can be done by a trial. The decision of the Constitutional Court in the trial of the Act is related to the formal and material aspects, then the verdict that has been fulfilled the legal considerations by the judge, it will become the basis of a decision. Therefore, the verdict can not revoked arbitrarily unless in making decision due to coercion or negligence. The thesis deals and focuses on two aspects: First, showing and analyzing the considerations of the Constitutional Court in deciding the case No.012-016-019 / PUU-IV / 2006, No.19 / PUU-V / 2017, No.37-39 / PUU-VIII / 2010, No.5 / PUU-IX / 2011, No.36 / PUU-XV / 2017. Second, explains why the Constitutional Court inconsistency in determining the status and legal position of the KPK (Corruption Eradication Commision) through its verdict. From the new latest verdict of the Constitutional Court said that the KPK is an independent state institution under the executive authority, it is different from the previous four Constitutional Court decisions which said KPK as an independent state institution.
\end{abstract}

Keywords: Decisions of the Constitutional Court, Inconsistency, Corruption Eradication Commission, Independent State Institution

\begin{abstract}
Abstrak
Mahkamah Konstitusi sebagaimana diamanatkan dalam konstitusi mempunyai fungsi sebagai penjaga konstitusi ( the guardian of the constitution) sehingga, jika ada norma-norma dalam UU yang bertentangan dengan UUD dapat dilakukan pengujian. Putusan Mahkamah Konstitusi dalam pengujian UU adalah berkaitan dengan aspek formil dan materil ,maka putusan yang sudah dikeluarkan telah memenuhi pertimbangan hukum oleh hakim sebagai dasar suatu putusan. Oleh karena itu, suatu putusan tersebut tidak dapat dicabut secara semena-mena, kecuali dalam pengambilan keputusan tersebut adanya paksaan atau kelalaian. Penelitian ini berfokus pada dua aspek yaitu, Pertama, mengkaji serta menganalisis pertimbangan Mahkamah Konstitusi dalam memutus perkara No.o12-016-019/PUU-IV/2006, No.19/PUU-V/2017, No.37-39/PUU-VIII/2010, No.5/PUU-IX/2011, No.36/PUU-XV/2017. Kedua, memaparkan mengapa Mahkamah Konstitusi Inkonsistensi dalam menentukan status dan kedudukan hukum KPK melalui putusannya. Penelitian ini menggunakan metode penelitian yuridis normatif. Dari putusan terbaru Mahkamah Konsitusi mengatakan bahwa KPK merupakan lembaga negara independen dibawah ranah eksekutif, hal tersebut berbeda dengan empat putusan MK sebelumnya yang mengatakan KPK sebagai lembaga negara independen.

Kata kunci: Putusan Mahkamah Konsititusi, Inkonsistensi, Komisi Pemberantasan Korupsi, Lembaga Negara Independen
\end{abstract}


Nommensen Journal of Legal Opinion (NJLO)

Jurnal Magister Hukum Program Pascasarjana Universitas HKBP Nommensen

Volume or Nomor o1 Juli 2020 Halaman. o1-26 e-ISSN: 2723-164X p-ISSN: 2722-9858

http://ejournal.uhn.ac.id/index.php/opinion

\section{A. Pendahuluan}

Undang-Undang Dasar Negara Kesatuan Republik Indonesia 1945, sebagai konstitusi tertulis di Indonesia dan juga merupakan refleksi dari cita-cita hukum bangsa Indonesia, secara eksplisit telah menggariskan beberapa prinsip dasar. Salah satu prinsip dasar yang mendapatkan penegasan dalam perubahan Undang- Undang Dasar 1945 (perubahan keempat) adalah prinsip negara hukum, sebagaimana telah tercantum secara eksplisit dalam Pasal 1 ayat (3) UUD 1945 yang menyatakan bahwa "Negara Indonesia adalah negara hukum". Dalam konsep Negara hukum itu, diidealkan bahwa yang harus dijadikan panglima dalam dinamika kehidupan kenegaraan adalah hukum, bukan politik ataupun ekonomi. Karena ada pepatah dalam Bahasa Inggris yang menyebut prinsip Negara Hukum adalah 'the rule of law, not of man'. Yang disebut pemerintahan pada pokoknya adalah hukum sebagai sistem, bukan perorang yang hanya bertindak sebagai 'wayang' dari skenario sistem yang mengaturnya. ${ }^{1}$

Gagasan Negara Hukum itu dibangun dengan mengembangkan perangkat hukum itu sendiri sebagai suatu sistem yang fungsional dan berkeadilan, dikembangkan dengan menata supra struktur dan infra struktur kelembagaan politik, ekonomi dan sosial yang tertib dan teratur, serta dibina dengan membangun budaya dan kesadaran hukum yang rasional dan impersonal dalam kehidupan bermasyarakat, berbangsa dan bernegara. Untuk itu, sitem hukum itu perlu dibangun (law making) dan ditegakkan (law enforcing) sebagaimana mestinya, dimulai dengan konstitusi sebagai hukum yang paling tinggi kedudukannya. Untuk menjamin tegaknya konstitusi itu sebagai hukum dasar yang berkedudukan tinggi (the supreme sebagai 'the guardian dan sekaligus 'the ultimate interpreter of the constitution)'. ${ }^{2}$ Menurut Julius Stahl', konsep Negara Hukum yang disebutnya dengan istilah 'rechsstaat' itu mencakup empat elemen penting, yaitu :

1. Perlindungan Hak Asasi Manusia.

2. Pembagian Kekuasaan.

3. Pemerintahan berdasarkan Undang- Undang.

4. Peradilan Tata Usaha Negara.

Sedangkan, menurut A.V. Dicey ${ }^{4}$ menguraikan adanya tiga ciri penting dalam setiap Negara Hukum yang disebutnya dengan istilah “The Rule of Law “, yaitu :

1. Supremacy of Law.

2. Equality before the law.

3. Due Procces of Law.

Keempat prinsip ' rechsstaat' yang dikembangkan oleh Julius Stahl tersebut diatas pada pokoknya dapat digabungkan dengan ketiga prinsip 'Rule of Law' yang dikembangkan oleh A.V. Dicey untuk menandai ciri-ciri Negara Hukum modern di zaman sekarang. Bahkan, oleh “The International Commissions of Jurist”, prinsip-prinsip Negara Hukum itu ditambah lagi dengan prinsip peradilan bebas dan tidak memihak (Independence and Impartiality of Judiciary) yang di zaman sekarang semakin dirasakan mutlak diperlukan dalam setiap negara demokrasi. Prinsip-prinsip yang dianggap ciri penting Negara Hukum menurut "The International and Commission of Jurists" ${ }^{\prime}$ itu adalah : Negara harus tunduk dan patuh terhadap hukum; Pemerintah menghormati hak-hak individu; Peradilan yang bebas dan tidak memihak.

Utrecht membedakan antara Negara Hukum Formil atau Negara Hukum Klasik, dan Negara Hukum Materil atau Negara Hukum Modern. Negara Hukum Formil menyangkut

\footnotetext{
${ }^{1}$ Jimly Asshiddiqie, Gagasan Negara Hukum Indonesia, Jakarta: Majalah Hukum Indonesia, 2005, hlm.1

${ }^{2}$ Ibid, hlm. 1

${ }^{3}$ Ibid, hlm.2

${ }^{4}$ Ibid, hlm.3

${ }^{5}$ Ibid
} 
pengertian hukum yang bersifat formil dan sempit, yaitu dalam arti peraturan perundangundangan tertulis. Sedangkan yang kedua yaitu Negara Hukum Materil yang lebih mutakhir mencakup pula pengertian keadiln didalamnya. Karena itu Wolfgang Friedman dalam bukunya 'Law in a Changing Society' membedakan antara 'Rule of Law' dalam arti formil yaitu dalam arti 'organized public power' dan 'rule of law' dalam arti materil yaitu 'the rule of just law'. Pembedaan ini dimaksudkan untuk menegaskan bahwa dalam konsepsi negara hukum itu, keadilan tidak serta merta akan terwujud secara substantif, terutama karena pengertian orang mengenai hukum itu sendiri dapat dipengaruhi oleh aliran pengertian hukum formil dan dapat pula dipengaruhi oleh aliran pikiran hukum materil. Jika hukum dipahami secara kaku dan sempit dalam arti peraturan perundang-undangan saja, niscaya pengertian terhadap Negara Hukum yang dikembangkan juga bersifat sempit dan terbatas serta belum tentu menjamin keadilan substantif. Karena itu di samping istilah 'the rule of law' oleh Friedman yang dikembangkan dengan istilah 'the rule of just law ' untuk memastikan bahwa pengertian kita tentang 'the rule of law tercakup pengertian keadilan yang lebih esensial daripada sekedar memfungsikan peraturan perundang-undangan dalam arti sempit. Adapun istilah yang digunakan tetap 'the rule of law', pengertian yang bersifat luas itulah yang diharapkan dicakup dalam istilah 'the rule of law' yang digunakan untuk menyebut konsepsi tentang Negara Hukum di zaman modern sekarang ini.

Menurut pendapat Janpatar Simamora, cita hukum negara Indonesia bersumber dari Pancasila yang merupakan filosofische gronslag dan common platform sebagai dasar negara. Oleh sebab itu, maka aktivitas lembaga pembuat hukum harus dimuarakan pada nilai-nilai common platform tersebut yang sarat dengan budaya, nilai-nilai yang hidup dalam masyarakat atau kearifan-kearifan lokal (local wisdom) yang melekat di dalamnya. ${ }^{6}$ Mahkamah Konstitusi Republik Indonesia merupakan salah satu lembaga baru dalam ketatanegaraan Republik Indonesia sebagai salah satu hasil dari tuntutan reformasi yaitu dengan adanya perubahan Undang- Undang Dasar 1945 (Constitutional Reform). Kehadiran Mahkamah Konstitusi dalam struktur ketatanegaran Indonesia merupakan kemajuan besar, tidak saja bagi pembangunan hukum melainkan juga bagi perkembangan demokrasi Indonesia. Kehadiran Mahkamah Konstitusi segenap wewenang dan kewajibannya, dinilai telah merobohkan doktrin supremasi parlemen (parliamentary supremacy) dan menggantikankan dengan ajaran supremasi konstitusi. Pasal 24 ayat 2 UUD 1945 yang menyatakan : "Kekuasaan Kehakiman dilakukan oleh sebuah Mahkamah Agung dan badan peradilan umum, lingkungan peradilan umum, lingkungan peradilan agama, lingkungan peradilan militer,lingkungan peradilan tata usaha negara dan sebuah Mahkamah Konstitusi".

Hal ini menandakan bahwa kekuasaan kehakiman merupakan satu kesatuan sistem yang dilakukan oleh Mahkamah Agung dan Mahkamah Konstitusi yang mencerminkan puncak kedaulatan hukum Indonesia berdasarkan UUD 1945. Mahkamah Konstitusi kemudian diatur dengan Undang-undang Nomor 24 tahun 2003 tentang Mahkamah Konstitusi yang disahkan pada tanggal 13 Agustus 2003. Namun Lembaga Mahkamah Konstitusi sendiri baru benarbenar ada pada tanggal 17 Agustus 2003 setelah pengucapan sumpah jabatan (9) sembilan hakim Konstitusi pada tanggal 16 Agustus 2003. Keberadaan Lembaga Mahkamah Konstitusi sebagai lembaga peradilan tersendiri diperkenalkan oleh pakar hukum Austria, Hans Kelsen (1881-1973) yang menyatakan bahwa pelaksanaan aturan konstitusional tentang legislasi dapat secara efektif dijamin hanya jika suatu organ selain badan legislatif diberikan tugas untuk

\footnotetext{
${ }^{6}$ Janpatar Simamora, Tafsir Makna Negara Hukum dalam Perspektif Undang-Undang Dasar Negara Republik Indonesia Tahun 1945, Jurnal Dinamika Hukum FH Universitas Jenderal Soedirman, Vol. 14 No. 3 September 2014, hlm. 558 .
} 
menguji apakah suatu produk hukum itu konstitusional atau tidak. Untuk itu dapat diadakan organ khusus seperti pengadilan khusus yaitu Mahkamah Konstitusi (constitutional court).

Menurut Hans Kelsen ${ }^{7}$ kemungkinan muncul persoalan konflik antara norma yang lebih tinggi dengan yang lebih rendah, bukan saja berkaitan antara undang-undang dan putusan pengadilan, tetapi juga berkaitan dengan hubungan antara konstitusi dan undang-undang. Ini adalah problem inkonstitusionalitas dari undang-undang. Suatu undang-undang (statute) hanya berlaku dan dapat diberlakukan jika sesuai dengan konstitusi, dan tidak berlaku jika bertentangan dengan konstitusi. Suatu undang-undang hanya sah jika dibuat berdasarkan ketentuan-ketentuan konstitusi. Karena itu diperlukan suatu badan atau pengadilan yang secara khusus untuk menyatakan inkonstitusionalitas dari suatu undang-undang yang sedang berlaku. Organ khusus yang mengontrol tersebut dapat menghapuskan sebagian atau keseluruhan undang-undang yang tidak konstitusional sehingga tidak dapat diterapkan oleh lembaga Negara yang lain. Gagasan ini kemudian terwujud dengan pembentukan Verfassungsgerichtshoft atau Mahkamah Konstitusi di Austria berdasarkan Konstitusi tahun 1920. Di Indonesia kewenangan Mahkamah Konstitusi didasarkan pada pasal 24 C UUD 1945, yang menyebutkan bahwa Mahkamah Kosntitusi berwenang mengadili pada tingkat pertama dan terakhir yang putusannnya bersifat final dalam : Menguji Undang-Undang terhadap Undang-Undang Dasar 1945; Memutuskan sangketa kewenangan Lembaga Negara yang kewenangan diberikan Undang-Undang Dasar 1945; Memutuskan pembubaran partai poltik; Memutuskan perselisihan tentang hasil pemilihan umum, dan wajib memberikan putusan atas pendapat DPR bahwa Persiden dan/atau wakil Presiden yang diduga telah melakukan pelanggaran hukum berupa pengkhianatan terhadap Negara, korupsi, penyuapan, tindak pidana berat lainnya, atau perbuatan tercela, dan atau tidak lagi memenuhi syarat sebagai Presiden dan/atau wakil Presiden sebagaimana dimaksud dalam UUD 1945.

Jimly Asshiddiqie menguraikan bahwa dalam konteks ketatanegaraan sebagai pengawal konstitusi yang berfungsi menegaskan konstitusional di tengah kehidupan masyarakat. ${ }^{8}$ Mahkamah Konstitusi bertugas mendorong dan menjamin agar konstitusi dihormati dan dilaksankan oleh semua komponen Negara secara konsisten dan bertanggung jawab. Di tengah kelemahan sistem konstitusi yang ada, Mahkamah Konstitusi berperan sebagai penafsir agar spirit konstitusi selalu hidup dan mewarnai keberlangsungan bernegara dan bermasyarakat.

Janpatar Simamora mengemukakan bahwa The Constitutional Court of Indonesia has 4 constitutional authorities, namely conducting a judicial review process of the law against the Constitution, resolving cases of authority dispute of state institutions whose authority comes from the constitution, decides the case of dissolution of political parties and decides on disputes over election results and has one the obligation is to decide on an impeachment case. ${ }^{9}$ Kewenangan pertama Mahkamah Konstitusi sering disebut sebagai "Constitutional review" merupakan perkembangan gagasan modern tentang sistem pemerintahan yang demokratis yang didasarkan atas ide Negara Hukum (rule of law), prinsip pemisahan kekuasaan (sepration of power), serta perlindungan hak asasi manusia ( the protection of fundamental right) dalam Constitutional review tercakup dua tugas pokok, yaitu yang pertama, menjamin berfungsinya sistem demokrasi dalam hubungan peran atau "interplay" antar cabang kekuasaan eksekutif, legislatif dan yudikatif. Constitutional review dimaksudkan untuk mencegah dominasi

\footnotetext{
${ }^{7}$ Hans Kelsen, General Theory of Law and State, Translated by Anders Wedberg, New York: Russel dan Russel, 1961, hlm.156.

${ }^{8}$ Cetak biru, Membangun Mahkamah Konstitusi, Sebagai Institusi Peradilan Konstitusi yang Modern dan Terpercaya, Seketariat Jendral MKRI,2004,hlm.4.

${ }^{9}$ Janpatar Simamora and Haposan Siallagan, Hans Kelsen's Thoughts On The Authority Model Of The Constitutional Of Indonesia, Journal of Talent Development \& Excellence, Vol. 12, No. 1, 2020, hlm. 4414.
} 
kekuasaan dan/atau penyalahgunaan kekuasaan oleh salah satu cabang kekuasaan; Kedua untuk melindungi setiap warga negara dari penyalahgunaan kekuasaan oleh lembaga Negara yang merugikan dan hak-hak dasar mereka yang dijamin oleh konstitusi. Kewenangan constitutional review sering juga disebut judicial review. Dalam perspektif teori konstitusi, dianutnya sistem judicial review adalah merupakan suatu bentuk dan upaya penguatan konsep negara hukum yang menempatkan konstitusi sebagai hukum tertinggi. ${ }^{10}$

Sedangkan kewenangan Mahkamah Konstitusi yang lain dapat dilihat sebagai upaya penataan hubungan kelembagaan Negara dan institusi dengan kewenangan tersebut, hubungan kelembagaan negara dan institusi demokrasi lebih didasarkan pada hubungan yang bersifat politik. Akibatnya, sebuah lembaga dapat mendominasi lembaga lain, atau terjadi pertentangan antar lembaga atau institusi yang melahirkan krisis konstitusional. Hal ini menimbulkan tidak adanya kepastian hukum dan kontra produktif terhadap pengembangan budaya demokrasi. Pengaturan kehidupan politik kenegaraan secara umum juga telah berkembang sebagai bentuk "the constitutionalization of democratic politics". Hal ini sematamata untuk mewujudkan supremasi hukum dan perkembangan demokrasi itu sendiri, berdasarkan konsep Negara hukum yang demokratis (democratishe reshsstat), berdasarkan kewenangan Mahkamah Konstitusi diberikan oleh UUD 1945, Mahkamah Kosntitusi mengemban fungsi sebagai penjaga konstitusi (the interpreter of the constitution), yakni bagaimana suatu ketentuan dalam UUD 1945 seharusnya ditafsirkan dan dilaksanakan terwujud dalam keputusan Mahkamah.

Dalam rangka menjalankan kewenangannya tersebut Mahkamah Konstitusi melalui Putusan Nomor 36/PUU-XV/2017 tanggal 8 Februari 2018 yang menyatakan bahwa Komisi Pemberantasan Korupsi (KPK) merupakan lembaga negara yang berada di ranah eksekutif. Mengingat sebelumnya Mahkamah Konstitusi pernah mengeluarkan Putusan Nomor o12-016019/PUU-IV/2006 tanggal 19 Desember 2006 , Putusan Nomor 19/PUU-V/2007 tanggal 13 November 2007, Putusan Nomor 37-39/PUU-VIII/2010 tanggal 15 Oktober 2010, Putusan Nomor 5/PUU-IX/2011 tanggal 20 Juni 2011, yang menyatakan pada intinya bahwa KPK merupakan lembaga independen yang bukan berada di dalam ranah eksekutif, legislatif, dan yudikatif. Dalam lima kerangka putusan tersebut terjadi ketidakkonsistenan putusan yang dikeluarkan Mahkamah Konstitusi, dimana empat kerangka putusan tersebut yang menyatakan bahwa KPK merupakan lembaga independen, artinya KPK tidak berada di bawah ranah eksekutif, legislatif, maupun yudikatif. Hal tersebut berbeda dengan dikeluarkan satu kerangka putusan MK terbaru yang menyatakan bahwa KPK merupakan lembaga yang berada di bawah ranah eksekutif. Seyogianya putusan Mahkamah Konstitusi bersifat final dan mengikat.

Dalam pembuatan sebuah Undang-undang, UU yang baru dibentuk bisa menghapus UU lama. Namun, hal serupa tidak berlaku di pengadilan. Di pengadilan, putusan lama tidak dapat dihapus dengan putusan baru. Hal demikian mendasari permasalahan yang timbul atas kebijakan putusan MK, sehingga diperlukan kajian yang lebih lanjut dan pertimbangan hukum atas kebijakan yang diambil oleh MK. Berdasarkan latar belakang yang telah dipaparkan diatas oleh penulis ingin meneliti lebih jauh mengenai "Inkonsistensi Putusan Mahkamah Konstitusi terhadap keberadaan Komisi Pemberantasan Korupsi sebagai lembaga Negara Independen”. Berdasarkan uraian diatas, maka rumusan masalah yang akan dikaji dalam penulisan ini adalah : Pertama, apakah yang menjadi pertimbangan Mahkamah Konstitusi dalam memutus perkara No. 012-016-019/PUU-IV/2006, No. 19/PUU-V/2017, No. 37-39/PUU-VIII/2010, No. 5/PUU-IX/2011, No. 36/PUU-XV/2017? Kedua, mengapa Mahkamah Konstitusi Inkonsistensi

\footnotetext{
${ }^{10}$ Janpatar Simamora, Analisa Yuridis Terhadap Model Kewenangan Judicial Review di Indonesia, Jurnal Mimbar Hukum FH Universitas Gadjah Mada Yogyakarta, Vol. 25 No. 3 Oktober 2013, hlm. 389.
} 
Nommensen Journal of Legal Opinion (NJLO)

Jurnal Magister Hukum Program Pascasarjana Universitas HKBP Nommensen

Volume or Nomor o1 Juli 2020 Halaman. o1-26 e-ISSN: 2723-164X p-ISSN: 2722-9858

http://ejournal.uhn.ac.id/index.php/opinion

dalam menentukan status dan kedudukan hukum Komisi Pemberantasan Korupsi melalui putusannya?

\section{B. Metode Penelitian}

Penelitian merupakan terjemahan dari bahasa inggris, yaitu research. Kata research berasal dari re (kembali) dan to search (mencari). Research berarti mencari kembali. Oleh karena itu penelitian berhubungan dengan upaya pencari pengetahuan dan suatu sarana pokok dalam pengembangan ilmu pengetahuan. Ruang lingkup penelitian adalah bertujuan untuk membatasi permasalahan yang akan dibahas dalam penelitian ini. Adapun ruang lingkup penelitian yang menjadi permasalahan adalah mengkaji putusan Mahkamah Konstitusi Nomor 37/PUU-XV/2017 dalam mengeluarkan putusan yang berbeda dengan putusan sebelumnya yaitu Putusan Nomor 012-016-019/PUU-IV/2006, Nomor 19/PUU-V/2007, Nomor 37-39/PUU-VIII/2010, Nomor 5/PUU-IX/2011 mengenai keberadaan KPK sebagai lembaga negara independen.

Penelitian ini berangkat dari kajian yang bersifat yuridis normatif. Dimana penelitian yurudis normatif ini sendiri adalah penelitian yang akan menjelaskan dan menjabarkan penelitian mengenai suatu hal dengan bersumber dari ketentuan-ketentuan hukum yang telah ada. Penelitian normatif yuridis ini dilakukan untuk bertujuan agar mengetahui apakah tema yang diangkat telah terlaksana dengan baik sesuai ketentuan-ketentuan yang ada. Hal ini dirumuskan melalui tujuan strategis yang ingin dicapai, apa masalah dan tantangannya, serta strategi kebijakan apa yang bisa diambil agar tujuan tercapai sekaligus bisa menjawab masalah dan tantangan yang dihadapi.

Penelitian ini dikaji dengan menggunakan metode Penelitian normatif dengan pendekatan perundang-undangan (statue approach), pendekatan kasus (case approach) dan pendekatan konseptual (conceptual approach). Pendekatan perundang-undangan (statue approach) yaitu memecahkan jawaban atas rumusan masalah yang diajukan denagn merujuk pada prinsip-prinsip hukum yang relevan. " Pendekatan kasus (case approach) yaitu memecahkan jawaban atas rumusan masalah yang diajukan dengan merujuk pada ratio decidendi, yaitu alasan- alasan hukum yang digunakan oleh hakim untuk sampai kepada putusannya. ${ }^{12}$ Pendekatan konseptual (conceptual approach) yaitu memecahkan jawaban atas rumusan masalah yang diajukan dengan merujuk pada konsep prinsip-prinsip hukum yang relevan. ${ }^{13}$

Untuk menunjang pelaksanaan penelitian digunakan bahan-bahan hukum, yaitu bahan hukum primer, bahan hukum sekunder dan bahan hukum tersier. Bahan hukum primer merupakan bahan hukum yang bersifat autoritatif artinya mempunyai kekuasaan. ${ }^{14}$ Bahan hukum tersebut merupakan norma yang bersifat mengikat. Sumber bahan hukum primer dari penelitian ini antara lain : Undang-Undang Dasar Negara Republik Indonesia 1945; UndangUndang Nomor 30 Tahun 2002 tentang Komisi Pemberantasan Tindak Pidana Korupsi; Undang-Undang Nomor 17 Tahun 2014 tentang Majelis Permusyawaratan Rakyat, Dewan Perwakilan Rakyat, Dewan Perwakilan Daerah, Dewan Perwakilan Rakyat Daerah; UndangUndang Nomor 48 Tahun 2009 perubahan atas Undang- Undang Nomor 4 Tahun 2004 tentang Kekusaan Kehakiman; Undang-Undang Nomor 8 tahun 2011 tentang perubahan atas Undang-Undang Nomor 24 Tahun 2003 tentang Mahkamah Konstitusi; Undang- Undang Nomor 12 tahun 2011 tentang perubahan atas Undang- Undang Nomor 10 Tahun 2004 Tentang

\footnotetext{
${ }^{11}$ Peter Mahmud Marzuki, Penelitian Hukum, Kencana Prenamedia Group,Jakarta,2007, hlm.97

${ }^{12}$ Ibid,hlm.119

${ }^{13}$ Ibid,hlm.138

${ }^{14}$ Ibid,hlm.141
} 
Pembentukan Peraturan Perundang-undangan; Peraturan Mahkamah Konstitusi tentang Pedoman Beracara dalam Perkara Pengujuan Undang-Undang Republik Indonesia,PMK No.06/PMK/2005; Putusan Mahkamah Konstitusi Nomor 012-016-019/PUU-IV/2006, tanggal 19 Desember 2006 Mahkamah Konstitusi Republik Indonesia, Pengujian UU Nomor 30 tahun 2002 tentang Komisi Pemberantasan Tindak Pidana Korupsi terhadap UUD NRI 1945; Putusan Mahkamah Konstitusi Nomor 19/PUU-V/2007 tanggal 13 November 2007 Mahkamah Konstitusi Republik Indonesia, Pengujian UU Nomor 30 tahun 2002 tentang Komisi Pemberantasan Tindak Pidana Korupsi terhadap UUD NRI 1945; Putusan Mahkamah Konstitusi Nomor 37-39/PUU-VIII/2010 tanggal 15 Oktober 2010 Mahkamah Konstitusi Republik Indonesia, Pengujian UU Nomor 30 tahun 2002 tentang Komisi Pemberantasan Tindak Pidana Korupsi terhadap UUD NRI 1945; Putusan Mahkamah Konstitusi Nomor 5/PUU-IX/2011tanggal 20 Juni 2011 Mahkamah Konstitusi Republik Indonesia, Pengujian UU Nomor 30 tahun 2002 tentang Komisi Pemberantasan Tindak Pidana Korupsi terhadap UUD NRI 1945; Putusan Mahkamah Konstitusi Nomor 36/PUU-XV/2017 tanggal 8 Februari 2018 Mahkamah Konstitusi Republik Indonesia, Pengujian UU Nomor 17 Tahun 2014 tentang UU MD3 terhadap UUD NRI 1945.

Bahan hukum sekunder berupa semua publikasi tentang hukum yang bukan merupakan dokumen-dokumen resmi. Bahan hukum tersebut berfungsi untuk menjelaskan bahan hukum primer dan tidak bersifat autoritatif. Sumber bahan hukum primer dari penelitian ini berupa buku-buku teks hukum, pendapat-pendapat para sarjana baik yang dipublikasikan maupun tidak dipublikasikan yang ada kaitannya dengan permasalahan yang dibahas, artikel-artikel yang dimuat dalam jurnal hukum, media cetak, maupun internet yang ada kaitannya dengan permasalahan yang dibahas. Bahan Hukum Tersier, berupa bahan hukum yang mendukung bahan hukum primer dan bahan hukum sekunder dengan memberikan pemahaman dan pengertian atas bahan hukum lainnya seperti Kamus Hukum dan Kamus Bahasa Indonesia. ${ }^{15}$

Dalam penelitian ini, analisis bahan hukum dilakukan dengan cara menganalisis Putusan Mahkamah Konstitusi yang terbaru yaitu Nomor 36/PUU-XV/2017 mengenai status dan kedudukan hukum Komisi Pemberantasan Korupsi sebagai lembaga negara independen yang dikaitkan dengan Putusan Mahkamah Konstitusi sebelumnya yaitu Nomor 012-016-019/PUUIV/2006, Nomor 19/PUU-V/2007, Nomor 37-39/PUU-VIII/2010, Nomor 5/PUU-IX/2011 dan berbagai literatur yang berkaitan dengan masalah yang diteliti kemudian menyusunnya dengan sistematis untuk menjawab problematika yang diharapkan dapat mengembangkan ilmu hukum khususnya dalam hukum tata negara, serta memberikan pandangan serta pola pikir kritis mengenai kekonsistenan MK dalam mengeluarkan produk hukumnya sendiri yang disebut dengan Putusan Mahkamah Konstitusi.

\section{Pembahasan}

\section{Kewenangan Mahkamah Konstitusi dalam Pengujian Undang-Undang}

Negara Indonesia merupakan negara ke 78 yang memiliki lembaga pengadilan konstitusionalitas yang diberikan kewenangan untuk menguji materil sebuah undangundang. ${ }^{16}$ Negara Amerika Serikat merupakan negara yang pertama kali memperkenalkan fungsi pengadilan konstitusionalitas dengan kasus terkenal pada waktu itu, yaitu kasus "Marbury Vs Madison" tahun 1803. ${ }^{17}$ Ketua Mahkamah Agung Amerika Serikat John Marshall ${ }^{18}$

\footnotetext{
${ }^{15}$ Soerjono Soekanto dan Srimamudji, Panel Hukum Normatif, Jakarta: Raja Grafindo Persada, 2014 ,hlm.14

${ }^{16}$ Jimly Asshiddiqie dalam Pengantar Mahkamah Konstitusi Komplikasi Konstitusi Undang-Undang dan Peraturan di 78 negara, Pusat Studi Hukum Tata Negara, Universitas Indonesia,2003, hlm.1

${ }^{17}$ David P.Currie, The Constitution of the United States, A Prime for the people,Chicago dan Landon, The University of the Chicago Press,1998,hlm.14 dan Lawrence M.Friedman, America Law an Introduction,second edition,terjemahan
} 
adalah pertama kali menafsirkan konstitusi untuk membatalkan undang-undang yang sebelumnya telah disahkan oleh Kongres Amerika konstitusi Amerika Serikat. Oleh karena itu, kasus tersebut dapat dipandang sebagai judical interpretation, yakni perubahan konstitusi melalui penafsiran hakim atau pengadilan.

Mahkamah Konstitusi dalam menjalankan kekuasaan kehakiman yang merdeka untuk menyelenggarakan peradilan guna menegakkan hukum dan keadilan. Mahkamah Konstitusi dibentuk untuk menjamin konstitusi sebagai hukum tertinggi agar dapat ditegakkan, sehingga dapat dikatakan bahwa Mahkamah Konstitusi disebut dengan the guardian of the constitution. Kedudukan Mahkamah Konstitusi setingkat atau sederajat dengan Mahkamah Agung sebagai kekuasaan kehakiman yang merdeka ${ }^{19}$ dalam sistem ketatanegaraan Indonesia. Dalam menjalankan kewenangannya termasuk didalamnya adalah dalam hal menguji undang-undang terhadap undang-undang dasar, Mahkamah Konstitusi juga melakukan penafsiran konstitusi, sehingga Mahkamah Konstitusi juga disebut the sole Interpreter of the Constitution. Lembaga penafsir tunggal konstitusi, banyak hal dalam mengadili menimbulkan akibat terhadap kekuasaan lain dalam kedudukan berhadapan, terutama terhadap lembaga legislatif di mana produknya di review.

Janpatar Simamora mengemukakan bahwa after the third amendment to the 1945 Constitution, the authority to interpret the constitution especially in the context of disputes over the authority of state institutions was formulated as the authority of the Constitutional Court. This is in line with the efforts to establish the Constitutional Court in 2001 which was then crystallized in 2003. ${ }^{20}$ Kedudukan Mahkamah Konstitusi dalam sistem ketatanegaraan Indonesia adalah sebagai lembaga negara yang menjalankan fungsi yudisial dengan kompetensi objek perkara ketatanegaraan. Keberadaan Mahkamah Konstitusi dipahami sebagai pengawal konstitusi untuk memperkuat dasar-dasar konstitusionalisme dalam UUD 1945. Mahkamah Konstitusi sebagai salah satu pelaku kekuasaan kehakiman diharapkan mampu mengembalikan citra lembaga peradilan di Indonesia sebagai kekuasaan kehakiman yang merdeka yang dapat dipercaya dalam menegakkan hukum dan keadilan. Dasar filosofis dari wewenang dan kewajiban Mahkamah Konstitusi adalah keadilan substantif dan prinsipprinsip good governance. Selain itu juga teori-teori hukum juga memperkuat keberadaan Mahkamah Konstitusi sebagai lembaga negara pengawal dan penafsir konstitusi. Kehadiran Mahkamah Konstitusi beserta segenap wewenang dan kewajibannya, dinilai telah merubah doktrin parlamen (parliamentary supermacy) dan menggantikan dengan ajaran supremasi konstitusi. ${ }^{21}$

Keadilan substantif (substantive justice) merupakan bagian untuk tidak mengarahkan kepada persamaan, melainkan mengarahkan kepada bagian yang berpihak pada yang benar. Dalam penerapan keadilan substantif ini, pihak yang benar akan mendapakan kemenangan sesuai dengan bukti-bukti akan kebenarannya. Teori-teori yang menjadi dasar pentingnya reformasi konstitusi dan menjadi dasar wewenang serta kewajiban Mahkamah Konstitusi

\footnotetext{
wisnu basuki dalam buku Taufiqurahman Syahuri,Tafsir Konstitusi berbagai Aspek Hukum, Jakarta: Kencana,2001,hlm.109

${ }^{18}$ Ronal Dworkin, Taking Rights Seriously,Cambridge,Massachusetts:Harvad University Press,1978,hlm.142.Dikutip dari Ibid,hlm.109

${ }^{19}$ Miftakhul Huda, Ultra Petita dalam Pengujian Undang-Undang,dalam Jurnal Konstitusi Volume 4 Nomor 3 September 2007, Mahkamah Konstitusi Republik Indonesia,hlm.114

${ }^{20}$ Janpatar Simamora, Development of Constitutional Interpretation by Constitutional Court of Indonesia in the Context of State Institutions' Authority Dispute Settlement, IOSR Journal Of Humanities And Social Science (IOSRJHSS) Volume 24, Issue 12, Series. 3 December 2019, hlm. 45.

${ }^{21}$ Mariyadi Faqih,Nilai-Nilai Filosofi Putusan Mahkamah Konstitusi yang final dan Mengikat, dalam Jurnal Konstitusi Volume 7 Nomor 3 Juni 2010, Sekretarian Jendral dan Kepaniteraan Mahkamah Konstitusi,Jakarta,hlm.97.
} 
adalah teori kedaulatan rakyat, teori konstitusi, teori negara hukum demokrasi, teori kesejahteraan, teori keadilan dan teori kepastian hukum. Dasar yuridis wewenang Mahkamah Konstitusi berasal dari UUD 1945 yang diatur dalam Pasal $7 \mathrm{~A}$, Pasal $7 \mathrm{~B}$, Pasal ${ }_{24} \mathrm{C}$ dan dijabarkan dengan UU No.24 Tahun 2003 atas perubahan UU No.8 Tahun 2011 tentang Mahkamah Konstitusi. Terhadap perorangan, kesatuan masyarakat adat sepanjang masih hidup, badan hukum publik atau privat, lembaga negara, partai politik ataupun pemerintah dan Dewan Perwakilan Rakyat, jika hak dan/atau wewenang konstitusionalnya, dilanggar atau dirugikan dapat mengajukan permohonan ke Mahkamah Konstitusi. Pasal 24C ayat (1) dan ayat (2) menggariskan wewenang dan kewajiban Mahkamah Konstitusi sebagai berikut Mahkamah Konstitusi berwenang mengadili pada tingkat pertama dan terakhir yang putusannya bersifat final untuk : Menguji Undang-Undang terhadap Undang-Undang Dasar; Memutus sangketa kewenangan lembaga negara yang kewenangan diberikan oleh UndangUndang Dasar; Memutus pembubaran Partai Politik dan Memutus perselisihan tentang hasil Pemilu. Mahkamah Konstitusi juga wajib memberi putusan atas pendapat Dewan Perwakilan Rakyat mengenai dugaan pelanggaran Presiden dan/atau menurut UUD.

Wewenang Mahkamah Konstitusi tersebut secara khusus diatur lagi dalam pasal 10 Undang-Undang Mahkamah Konstitusi dengan merinci sebagai berikut, Menguji UndangUndang terhadap Undang-Undang Dasar Negara Republik Indonesia tahun 1945; Memutus sangketa kewenangan lembaga Negara yang kewenangannya diberikan oleh UUD 1945; Memutuskan pembubaran partai politik; Memutuskan perselisihan hasil pemilu. Sebagai organ konstitusi Mahkamah Konstitusi didesain untuk menjadi pengawal dan penafsir UUD melalui putusan-putusannya. Dalam menjalankan tugas konstitusionalnya, Mahkamah Konstitusi berupaya mewujudkan tegaknnya konstitusi dalam rangka mewujudkan cita negara hukum dan demokrasi demi kehidupan kebangsaan dan kenegaraan yang bermatabat. Mahkamah Konstitusi dalam menjalankan kekuasaan kehakiman yang diembannya secara merdeka dan bertanggung-jawab sesuai dengan amanat Undang-Undang Dasar Negara Kesatuan Republik Indonesia Tahun 1945. Mahkamah Konstitusi membuka diri untuk menerima permohonan setiap warga negara yang merasa hak-haknya dan kewenangan konstitusionalnya dilanggar akibat berlakunya suatu undang -undang. Landasan kerugian hak dan/atau kewenangan konstitusional diuraikan dalam Pasal 51 ayat (1) UU MK yang harus dipenuhi syarat- syarat sebagai berikut.

a. Adanya hak dan/ atau kewenangan konstitusional Pemohon yang diberikan oleh UUD 1945.

b. Hak dan/ atau kewenangan konstitusional tersebut, dianggap telah dirugikan oleh berlakunya suatu undang-undang yang dimohonkan pengujian.

c. Kerugian hak dan/ atau kewenangan konstitusional tersebut harus bersifat spesifik (khusus) dan aktual atau setidak-tidaknya potensial yang menurut penalaran yang wajar dapat dipastikan akan terjadi.

d. Adanya hubungan sebab-akibat (causal-verband) antara kerugian dimaksud dengan berlakunya undang-undang yang dimohonkan pengujian.

e. Adanya kemungkinan bahwa dengan dikabulkannya permohonan maka kerugian konstitusional tersebut tidak akan atau tidak lagi terjadi.

Konstitusi menjadi hukum tertinggi yang dapat ditegakkan sebagaimana mestinya melalui keberadaan Mahkamah Konstitusi yang dalam menjalankan fungsinya sebagai pengawal konstitusi, sebagai penafsir tunggal atas konstitusi. Janpatar Simamora dan Bintang ME Naibaho mengemukakan bahwa The country of Indonesia is a country of law. This is confirmed in section 1 paragraph (3) of the 1945 Constitution of the Republic of Indonesia. As a consequence of the adoption of a state of law for the Indonesian nation, all state and government activities must truly refer to existing legal rules. The emergence of ideas and thoughts of the rule 
of law is inseparable from the pattern of implementing state power that is vulnerable to arbitrary acts, so it is necessary to limit state power through legal instruments. ${ }^{22}$

Mahkamah Konstitusi dalam perkembangannya oleh sebagian penggiat hukum dikhawatirkan akan menjadi lembaga yang memiliki kewenangan super body. Khususnya dalam menyelesaikan perkara terkait dengan kewenangan yang melekat, Mahkamah Konstitusi secara sepihak dapat menafsirkan Undang- Undang Dasar tanpa dapat dipersoalkan, selain itu putusan yang dihasilkan Mahkamah Konstitusi bersifat final dan mengikat, sehingga ketika ada salah satu pihak yang merasa dirugikan dengan putusan Mahkamah Konstitusi tidak bisa melakukan upaya hukum yang lain kecuali ada bukti-bukti permohonan yang beralasan. Konsep judical review itu sendiri sebenarnya dilihat sebagai hasil perkembangan modern tentang sistem pemerintahan demokratis yang didasarkan atas ide-ide negara hukum (rule of law), prinsip pemisahan kekuasaan (seperation of power), serta perlindungan dan pemajuan hak-hak asasi manusia (the protection of fundamental rights) ${ }^{23}$. Pengujian peraturan perundang-undangan dapat dibagi berdasarkan subyek yang melakukan pengujian, obyek peraturan yang diuji, dan waktu pengujian. Dilihat dari segi subyek yang melakukan pengujian, pengujian dapat dilakukan oleh hakim (toetsingsrecht van de rechter atau judical review), pengujian oleh lembaga legislatif (legislatif review), maupun pengujian oleh lembaga eksekutif (executive review). ${ }^{24}$ Indonesia mengatur ketiga pengujian tersebut. Pengujian oleh hakim (toetsingsrecht van de rechter atau judical review) diatur baik sebelum dan sesudah perubahan UUD 1945. ${ }^{25}$

Pengaturan mengenai pengujian peraturan perundang-undangan pada masa berlakunya UUD 1945, pertama kali diatur dalam Undang- Undang No. 14 Tahun 1970 tentang Ketentuanketentuan Pokok Kekuasaan Kehakiman, yang mengatur pengujian terhadap peraturan perundang-undangan dibawah UU terhadap UU yang merupakan kewenangan Mahkamah Agung. Setelah perubahan UUD 1945, kewenangan pengujian peraturan perundanganundangan di bawah UU terhadap UU tetap merupakan kewenangan Mahkamah Agung, sedangkan pengujian UU terhadap UUD merupakan kewenangan Mahkamah Konstitusi. Pengujian UU oleh lembaga legislatif (legislative review) dilakukan dalam kapasitas sebagai lembaga yang membentuk dan membahas serta menyetujui UU (bersama-sama Presiden). Sebelum perubahan UUD 1945, pengujian UU terhadap UUD berada pada MPR berdasarkan Ketetapan MPR RI Nomor III/MPR/ 2000 tentang Sumber Hukum dan Tata Urutan Peraturan Perundang-Undangan.

Alasan mengapa Mahkamah Agung mempunyai wewenang menguji hanya terhadap peraturan perundang-undangan dibawah UU terhadap UU pada masa sebelum perubahan UUD 1945, menurut Padmo Wahjono didasarkan pada pemikiran bahwa UU sebagai konstruksi yuridis yang maksimal untuk mencerminkan kekuasaan tertinggi pada rakyat, sebaiknya diuji/diganti/diubah oleh yang berwenang membuatnya, yaitu DPR. Berdasarkan praktik kenegaraan yang pernah berlaku. ${ }^{26}$ Sebagaimana pengujian lembaga legislatif

\footnotetext{
${ }^{22}$ Janpatar Simamora dan Bintang ME Naibaho, Statutory of The Republic of Indonesia Witness As a Government Institution Implementing Country's Power in The Indonesian State Concerns System, Proceedings of the First Nommensen International Conference on Creativity \& Technology, NICCT, 20-21 September 2019, Medan, North Sumatera, Indonesia. Lihat juga dalam Janpatar Simamora, Kepastian Hukum Pengajuan Kasasi oleh Jaksa Penuntut Umum Terhadap Vonis Bebas, Jurnal Yudisial, Komisi Yudisial RI, Volume 7 Nomor 1 April 2014, page 1-17.

${ }^{23}$ Herbert Hausmaininger,The Austrian Legal Sistem,Wien,2003,hlm.139 dalam Jimly Asshiddiqie, Model-model Pengujian Konstitusional di berbagai Negara ,Jakarta : Sinar Grafika,2010, ( selanjutnya disingkat Jimly Asshiddiqie I),hlm.8.

${ }^{24}$ Sekretariat Jendral dan Kepaniteraan Mahkamah Konstitusi Republik Indonesia,Hukum Acara Mahkamah Konstitusi, Jakarta :Cetakan Pertama Agustus ,2010, hlm.82.(selanjutnya disebut Hukum Acara MK).

${ }^{25}$ Ibid

${ }^{26}$ Padmo Wahjono,Indonesia Negara Berdasarkan Atas Hukum, Cetakan 2, Jakarta, Ghalia Indonesia,1986, hlm.15.
} 
(legislative reviw) yang dilakukan dalam kapasitas sebagai lembaga yang membentuk dan membahas serta menyetujui UU (bersama dengan Presiden), pemgujian oleh lembaga eksekutif (executive review) dilakukan terhadap peraturan perundang-undangan yang dibentuk oleh lembaga eksekutif. Analisis mendalam diperlukan jika mengkaji pengujian peraturan dari segi objeknya, karena harus memperhatikan sistem hukum yang digunakan, sistem pemerintahan, dan sejarah ketatanegaraan dari sebuah negara sehingga sangat mungkin terdapat ciri kekhasan pada negara tertentu.

Dilihat dari obyek yang diuji, maka peraturan perundang-undangan yang diuji terbagi atas : Seluruh peraturan perundang-undangan (legislative acts dan executive acts) dan tindakan administratif (administrative action) terhadap UUD diuji oleh hakim pada seluruh jenjang peradilan. Pengujian dengan obyek seperti ini dilakukan dalam kasus yang kongkrit, dan secara umum dilakukan pada negara yang menggunakan common law system. ${ }^{27}$ Secara umum istilah yang digunakan adalah judical review, akan tetapi perlu diperhatikan kembali penggunaan istilah itu pada negara- negara yang menggunakan sistem hukum civil law system. UU terhadap UUD diuji oleh hakim-hakim Mahkamah Konstitusi (Constitutional review), sedangkan peraturan perundang-undangan dibawah UU terhadap UU diuji oleh hakim- hakim di Mahkamah Agung (Supreme Court). Pengujian dengan pembagian obyek seperti ini secara umum tidak dilakukan dalam kasus yang kongkrit, dan secara umum dilakukan pada negara yang menggunakan sistem hukum civil law. Jimly Asshiddiqie membedakan jika pengujian itu dilakukan terhadap norma hukum yang bersifat abstrak dan umum secara " a posteriori ", maka pegujian itu dapat disebut sebagai "judical review "akan tetapi jika ukuran pengujian itu dilakukan dengan menggunakan konstitusi sebagai alat pengukur, maka kegiatan pengujian semacam itu dapat disebut sebagai "constitutional review" atau pengujian konstitusional yaitu mengenai konstitusionalitas dari norma hukum yang sedang diuji (judical review on the constitutionality of law). ${ }^{28}$

Konsep constitutional review adalah merupakan buah dari perkembangan gagasan modern tentang sistem pemerintahan demokratis yang sebelimnya sudah dijelaskan didasarkan atas ide-ide Negara Hukum (rule of law), prinsip pemisahaan kekuasaan (seperation of power), serta perlindungan dan pemajuan hak asasi manusia (the protection of fundamental rights). Dengan demikian, dalam sistem constitutional review tercakup dua tugas pokok, yaitu : a. Untuk menjamin perimbangan sistem demokrasi dalam dalam hubungan perimbangan peran antara cabang kekuasaan legislatif, eksekutif, dan yudisial. Dalam kerangka mencegah penyalahgunaan kekuasaan oleh suatu cabang Kekuasaan negara.

b. Untuk di masing-masing negara, untuk menegakkan konstitusi sebagai barometer penyelenggaraan kegiatan bernegara. ${ }^{29}$

Namun demikian, di setiap negara, konsep-konsep judical review berbeda-beda cakupan pengertiannya satu sama lain. Pengertian istilah-istilah itu juga tidak boleh diidentikan antara satu negara dengan negara lain yaitu : Inggris, Amerika Serikat, Kanada dan Australia, meskipun sama-sama menggunakan bahasa inggris, tetapi sistem konstitusi dan sistem pengujian konstitusionalnya berbeda- beda satu sama lain. ${ }^{30}$ Konsep negara hukum, senantiasa meletakkan jaminan perlindungan hak-hak asasi manusia warga negaranya sebagai tujuan

\footnotetext{
${ }^{27}$ Black's Law, Judical review diartikan sebagai:power of courts to review decisions of another departmen or level of government."Henry Campbell Black.Black's Law Dictionary with Pronunciations.6 th ed. ( United States of America: West Publishing Co,1990),hlm.849. Encylopedia Americana mengemukan pengertian judical review sebagai berikut :"Judical review is the power of the courts of the country to determine if the acts of the legislature and executive are constitutional.

${ }^{28}$ Ibid

${ }^{29}$ Jimly Asshiddiqie I,Op.Cit,hlm.10-11

${ }^{30}$ Ibid.hlm.12
} 
utamanya, dimana di Indonesia diatur kemudian dalam UU No. 39 Tahun $1999 .{ }^{31}$ Dalam penyelenggaraan ketatanegaran yang harus bersumber dari konstitusi sebagai hukum dasar. Mekanisme kontrol terhadap norma-norma hukum tersebut agar pembuatan dan substansi normanya tidak bertentangan dengan peraturan- peraturan yang lebih tinggi.

Selanjutnya, mengenai organ yang berbentuk organik, lebih luas lagi, setiap jabatan yang ditentukan oleh hukum dapat pula disebut organ, asalkan fungsi-fungsinya itu bersifat menciptakan norma (normcreating) dan/atau bersifat menjalankan norma (norm applying). "These functions, be they of a norm-creating or of a norm-applying character, are all ultimately aimed at the execution of a legal sanction". Untuk memberikan pemahaman yang lebih komprehensif mengenai definisi lembaga negara, berikut akan diuraikan sejumlah definisinya. Menurut Janpatar Simamora, secara sederhana bahwa yang dimaksud dengan lembaga negara adalah alat kelengkapan negara atau istilah lain yang dipergunakan untuk itu yang berfungsi untuk melaksanakan dan menjalankan tugas pokok kekuasaan negara. Istilah lembaga negara juga sering disebut dengan istilah lain seperti lembaga pemerintahan, penyelenggara negara atau sejumlah istilah lain. ${ }^{32}$

Antara lembaga negara dengan lembaga pemerintahan pada hakikatnya masih dimungkinkan dibedakan secara lebih spesifik. Adapun yang dimaksud dengan lembaga pemerintahan pada dasarnya mengacu pada istilah "pemerintah “. Sedangkan pengertian pemerintah dalam arti sempit adalah pelaksanaan kekukasaan eksekutif. Dengan demikian, maka lembaga pemerintahan dapat dipahami sebagai lembaga yang menjalankan fungsi kekuasaan eksekutif. Sementara lembaga negara merujuk pada definisi yang lebih luas, yaitu termasuk di dalamnya kekuasaan eksekutif, legislatif, yudikatif. Ada juga yang membedakan lembaga negara berdasarkan dasar hukum pembentukannya.

Pertimbangan Mahkamah Konstitusi dalam Memutus Perkara No. 36/PUU-XV/2017, dengan Perkara No.o12-o16-o19/PUU-IV/20o6, No.19/PUU-V/20o7,No.37-39/PUUVIII/2010, No. 5/PUU-IX/2011

Pertimbangan hakim adalah argumen atau alasan yang dipakai oleh hakim sebagai pertimbangan hukum yang menjadi dasar sebelum memutus perkara. Menurut Goodheart pertimbangan hakim dalam memutuskan suatu perkara inilah yang menunjukkan bahwa ilmu hukum merupakan ilmu yang bersifat perspektif, bukan deskriptif. Fakta materil menjadi fokus karena hakim maupun para pihak akan mencari dasar hukum yang tepat untuk diterapkan pada fakta kasus tersebut. Dalam menemukan pertimbangan hakim dalam suatu putusan biasanya terdapat pada bagian-bagian tertentu. Untuk sampai kepada salah satu putusan itu hakim harus menuliskan alasan-alasannya, yaitu pertimbangan hukum. Di dalam hukum Indonesia yang menganut civil law system, pertimbangan hakim tersebut dapat ditemukan pada konsideran "Menimbang" pada "Pokok Perkara". Tidak dapat disangkal bahwa tindakan hakim untuk memberikan alasan-alasan yang mengarahkan kepada putusan merupakan tindakan yang perlu mempunyai insting menafsirkan suatu undang-undang secara kreatif. Pertimbangan hakim dapat ditemukan dengan memperhatikan fakta materil dan putusan yang didasarkan atas fakta. Dengan demikian, dari suatu fakta materil dapat terjadi dua kemungkian putusan yang saling berlawanan, yang menentukan adalah pertimbangan hakim tersebut. Dalam hal ini dapat disimpulkan bahwa Mahkamah Konstitusi dalam

\footnotetext{
${ }^{31}$ Sara Tambun, Goncalwes Sirait, Janpatar Simamora, Analisis Yuridis Hak dan Kewajiban Warga Negara Menurut Undang-Undang Nomor 20 Tahun 2003 tentang Sistem Pendidikan Nasional, Jurnal Visi Ilmu Sosial Humaniora, Vol. 1 No. o1 Juni 2020, hlm. 87.

${ }^{32}$ Janpatar Simamora, Problematika Penyelesaian Sangketa Kewenangan Lembaga Negara oleh Mahkamah Konstitusi, Jurnal Mimbar Hukum FH UGM Yogyakarta, Volume 28, Nomor 1, Februari 2016, hlm.8o.
} 
mengambil keputusan tentu mempertimbangkan berbagai aspek. Salah satunya adalah pendapat para hakim, sehingga pertimbangan hukum oleh hakim Mahkamah Konstitusi menjadi pertimbangan yang tidak boleh dikesampingkan dalam mengambil keputusan.

\section{Putusan Mahkamah Konstitusi No.o12-016-019/PUU-IV/2006}

Mahkamah Konstitusi merupakan satu-satunya lembaga peradilan yang diberikan kewenangan untuk mengadili tingkat pertama dan terakhir yang putusannya bersifat final dan mengikat untuk menguji undang-undang terhadap Undang-Undang Dasar sebagaimana telah tercantum secara eksplisit dalam Pasal 24 ayat (1) UUD. Di dalam mengeluarkan putusan No.012-016-019/PUU-IV/2006 dasar yang dipergunakan Mahkamah Konstitusi untuk memutuskannya ialah UUD 1945. Putusan MK No.o12-016-019/PUU-IV/2006, dalam gugatan uji materi konstitusionalitas Pasal 1 angka 3,Pasal 2, Pasal 3, Pasal 11 huruf b, Pasal 12 ayat 1,Pasal 20 ayat 1 dan ayat 2, Pasal 40, Pasal 53, Pasal 72 Undang-Undang Nomor 30 Tahun 2002 tentang Komisi Pemberantasan Tindak Pidana Korupsi terhadap Undang- Undang Negara Republik Indonesia Tahun 1945. Adanya tiga pemohon yaitu :

Pemohon I ( Mulyana Wirakusumah)

Pemohon II (Nazaruddin Sjamsuddin, Ramlan Surbakti, Rusadi Kantaprawira, Daan Dimara, Chusnul Mar'iyah, Valina Singka Subekti, Safder Yusacc, Hamdani Amin, R. Bambang Budiarto) Pemohon III (Cap. Tarcisius Walla).

Dalam konklusinya Mahkamah Konstitusi mempertimbangkan Pasal 1 angka 3, Pasal 2, Pasal 3, Pasal 11 huruf b, Pasal 12 ayat 1,Pasal 20 ayat 1 dan ayat 2, Pasal 40, Pasal 72 UndangUndang Nomor 30 Tahun 2002 tentang Komisi Pemberantasan Tindak Pidana Korupsi tidak bertentangan dengan Undang- Undang Dasar Negara Republik Indonesia Tahun 1945 serta dalil-dalil permohonan Para Pemohon tidak beralasan, kecuali Pasal 53 dianggap bertentangan dengan Undang- Undang Dasar Negara Republik Indonesia Tahun 1945. Menyatakan Pasal 53 Undang-Undang Nomor 30 Tahun 2002 tentang Komisi Pemberantasan Tindak Pidana Korupsi (Lembaran Negara Republik Indonesia Tahun 2002 Nomor 137, Tambahan Lembaran Negara Republik Indonesia Nomor 4250) tetap mempunyai kekuatan hukum mengikat sampai diadakan perubahan paling lambat 3 (tiga) tahun terhitung sejak putusan ini diucapkan. Dalam Amar Putusannya menyatakan dengan mengingat Undnag-Undang Dasar NRI Tahun 1945 dan Pasal 56 Ayat (2), Ayat (3), dan Ayat (5), Pasal 57 Ayat (1) dan Ayat (3), serta Pasal 58 Undang-Undang Nomor 24 Tahun 2003 tentang Mahkamah Konstitusi (Lembaran Negara Republik Indonesia Tahun 2003 Nomor 98, Tambahan Lembaran Negara Republik Indonesia Nomor 4316).

1. Menyatakan permohonan Pemohon II dikabulkan untuk sebagian

2. Menyatakan permohonan Pemohon II ditolak untuk selebihnya;

3. Menyatakan permohonan Pemohon I ditolak untuk seluruhnya;

4. Menyatakan permohonan Pemohon III ditolak untuk seluruhnya;

5. Memerintahkan pemuatan putusan ini dalam Berita Negara Republik Indonesia sebagaimana mestinya.

Adapun yang menjadi pertimbangan hukum oleh Mahkamah Konstitusi yaitu :

Pasal 3 UU KPK berbunyi, "Komisi Pemberantasan Korupsi adalah lembaga negara yang dalam melaksanakan tugas dan wewenangnya bersifat independen dan bebas dari pengaruh kekuasaan mana pun." Pemohon II mendalilkan bahwa frasa "bersifat independen dan bebas dari pengaruh kekuasaan mana pun" dalam Pasal 3 UU KPK menunjukkan bahwa KPK memiliki kekuasaan yang absolut; Mahkamah berpendapat bahwa rumusan dalam Pasal 3 UU KPK itu sendiri telah tidak memberikan kemungkinan adanya penafsiran lain selain yang terumuskan dalam ketentuan pasal dimaksud, yaitu Bahwa independensi dan bebasnya KPK dari pengaruh 
kekuasaan mana pun adalah dalam melaksanakan tugas dan wewenangnya. Tidak terdapat persoalan konstitusionalitas dalam rumusan Pasal 3 UU KPK tersebut: bahwa penegasan tentang independensi dan bebasnya KPK dari pengaruh kekuasaan mana pun dalam melaksanakan tugas dan wewenangnya justru menjadi penting agar tidak terdapat keraguraguan dalam diri pejabat KPK. ${ }^{33}$

\section{Putusan Mahkamah Konstitusi No.19/PUU-V/2007}

Permohonan uji materi Undang-Undang Nomor 30 Tahun 2002 tentang Komisi Pemberantasan Tindak Pidana Korupsi sebagaimana dimaksud diajukan oleh Ravavi Wilson yang disebut sebagai Pemohon. Adapun muatan pasal yang dilakukan pengujian oleh pemohon adalah Pasal 29 huruf d UU No.30 Tahun 2002. Dalam konklusinya penilaian Mahkamah Konstitusi diuraikan berkesimpulan :

a. bahwa Pasal 29 huruf d UU KPK yang memuat syarat untuk menjadi Pimpinan KPK harus "berijazah sarjana hukum atau sarjana lain yang memiliki keahlian dan pengalaman sekurang-kurangnya 15 (lima belas) tahun dalam bidang hukum, ekonomi, keuangan, atau perbankan", tidak bertentangan dengan Pasal 28D Ayat (3), Pasal 28H Ayat (2), Pasal 28I Ayat (5) dan Pasal 28 J Ayat (1) UUD 1945.

b. bahwa dengan demikian permohonan pengujian ketentuan a quo tidak beralasan dan oleh karena itu permohonan Pemohon harus dinyatakan ditolak. ${ }^{34}$

Berikut amar putusan menyatakan mengingat Pasal 56 Ayat (5) Undang-Undang Nomor 24 Tahun 2003 tentang Mahkamah Konstitusi (Lembaran Negara Republik Indonesia Tahun 2003 Nomor 98, Tambahan Lembaran Negara Republik Indonesia Nomor 4316). Menyatakan permohonan Pemohon ditolak untuk seluruhnya. Adapun yang menjadi pertimbangan hukum oleh Mahkamah Konstitusi yaitu : Bahwa, sebagaimana telah diterangkan oleh DPR maupun Pemerintah, tindak pidana korupsi yang telah meluas secara sistematis sedemikian rupa sehingga merugikan keuangan negara, perekonomian negara, dan menghambat pembangunan nasional, yang dengan demikian sesungguhnya telah melanggar hak-hak sosial dan ekonomi masyarakat, tidak dapat lagi digolongkan sebagai kejahatan biasa melainkan telah menjadi kejahatan luar biasa (extra-ordinary crime). Bahkan, masyarakat internasional pun secara tidak langsung mengakui sifat luar biasa dari tindak pidana korupsi tersebut, sebagaimana tampak dalam Preamble dari United Nations Convention against Corruption yang menyatakan, antara lain, "Concerned about the seriousness of problems and threats posed by corruption to stability and security of societies, undermining the institutions and values of democracy and the rule of law, concerned also about the links between corruption and other forms of crime, in particular organized crime and economic crime, including money-laundering, concerned further about cases of corruption that involve vast quantities of assets, which may constitute a substantial proportion of the resources of States, and that threaten the political stability and sustainable development of those States, Convinced that corruption is no longer a local matter but a transnational phenomenon that affects all societies and economies, making international cooperation to prevent and control it essential...." Sedemikian luar biasa sifat tindak pidana korupsi tersebut sehingga pembentuk undang-undang pun menyadari dan mengakui bahwa institusi-institusi yang telah ada (sebelum dibentuknya Komisi Pemberantasan Tindak Pidana Korupsi) belum optimal dalam melaksanakan fungsinya untuk memberantas tindak pidana korupsi (vide Konsiderans huruf a dan Penjelasan Umum UU KPK). Oleh karena itu, pembentuk undang-undang memandang perlu membentuk suatu lembaga tersendiri, yaitu Komisi Pemberantasan Tindak Pidana Korupsi (KPK), yang diberi kewenangan besar dan

\footnotetext{
${ }^{33}$ Putusan Mahkamah Konstitusi No.012-016-019/PUU-IV/2006,hlm.269

${ }^{34}$ Putusan Mahkamah Konstitusi No.19/PUU-V/2007,hlm.43
} 
tugas-tugas yang sangat luas dalam rangka mencegah dan memberantas tindak pidana korupsi.

Dengan mempertimbangkan luasnya wewenang dan tugas KPK dimaksud, syarat keahlian dan/atau keterampilan serta profesionalitas jelaslah merupakan keniscayaan yang harus dimiliki oleh setiap orang yang hendak diberi wewenang dan tugas itu. Oleh karena itu, jika kemudian pembentuk undang-undang menetapkan persyaratan yang cukup berat untuk mengisi jabatan Pimpinan KPK, maka persyaratan demikian adalah persyaratan yang dapat diterima oleh penalaran yang wajar.

\section{Putusan Mahkamah Konstitusi No.37-39/PUU-VIII/2010}

Putusan Mahkamah Konstitusi No.37-39/PUU-VIII/2010 dalam melakukan Gugatan uji materi Undang- Undang Nomor 30 Tahun 2002 tentang Komisi Pemberantasan Tindak Pidana Korupsi sebagaimana dimaksud diajukan oleh M. Farhat Abbas, yang disebut sebagai Pemohon I dan O.C.Kaligis yang disebut sebagai Pemohon II. Adapun muatan pasal yang dilakukan pengujian oleh pemohon adalah Pasal 29 angka 4 dan angka 5 Undang-Undang Nomor 30 Tahun 2002. Dalam Konklusinya Mahkamah Konstitusi menimbang bahwa berdasarkan penilaian hukum dan fakta berkesimpulan bahwa :

a. Mahkamah berwenang memeriksa, mengadili, dan memutus permohonan a quo;

b. Para Pemohon memiliki kedudukan hukum (legal standing)

c. Permohonan provisi para Pemohon tidak beralasan hokum

d. Dalil-dalil para Pemohon tidak berdasar dan tidak beralasan hukum.

Berdasarkan Undang-Undang Dasar Negara Republik Indonesia Tahun 1945 dan Pasal 56 ayat (5) Undang-Undang Nomor 24 Tahun 2003 tentang Mahkamah Konstitusi (Lembaran Negara Republik Indonesia Tahun 2003 Nomor 98,Tambahan Lembaran Negara Republik Indonesia Nomor 4316), Undang-Undang Nomor 48 Tahun 2009 tentang Kekuasaan Kehakiman (Lembaran Negara Republik Indonesia Tahun 2009 Nomor 157, Tambahan Lembaran Negara Republik Indonesia Nomor 5076). Adapun amar putusan menyatakan :

Dalam Provisi : - Menolak provisi para Pemohon.

Dalam Pokok Permohonan : - Menolak permohonan para Pemohon untuk seluruhnyaa.

Berikut yang menjadi pertimbangan hukum oleh Mahkamah Konstitusi dalam memutus perkara yaitu : Menimbang bahwa terhadap persoalan hukum tersebut Mahkamah mempertimbangkan bahwa Komisi Pemberantasan Korupsi adalah lembaga negara yang bersifat independen yang dalam melaksanakan tugas dan wewenangnya bebas dari kekuasaan manapun, yang Pimpinannya terdiri dari 5 (lima) orang yang merangkap sebagai anggota yang terdiri atas unsur pemerintah dan unsur masyarakat dengan tujuan agar sistem pengawasan yang dilakukan oleh masyarakat terhadap kinerja Komisi Pemberantasan Korupsi dalam melakukan penyelidikan, penyidikan, dan penuntutan terhadap tindak pidana korupsi tetap melekat pada Komisi Pemberantasan Korupsi. ${ }^{35}$

\section{Putusan Mahkamah Konstitusi No. 5/PUU-IX/2011}

Permohonan uji materi Undang-Undang Nomor 30 Tahun 2002 tentang Komisi Pemberantasan Tindak Pidana Korupsi sebagaimana dimaksud diajukan oleh Feri Amsari, Ardisal, Teten Masduki, Zainal Arifin Mochtar Husein yang disebut sebagai Pemohon I dan ICW ( Indonesia Corruption Watch dalam hal ini diwakili oleh Danang Widoyoko disebut sebagai Pemohon II. Adapun muatan pasal yang dilakukan pengujian oleh pemohon adalah Pasal 34 Undang-Undang Nomor 30 Tahun 2002. Dalam Konklusinya berdasarkan pertimbangan atas fakta dan hukum, Mahkamah Konstitusi berkesimpulan bahwa:

\footnotetext{
${ }^{35}$ Putusan Mahkamah Konstitusi No.37-39/PUU-VIII/2010,hlm.57
} 
a. Mahkamah berwenang untuk memeriksa, mengadili, dan memutus permohonan a quo.

b. Para Pemohon memiliki kedudukan hukum (legal standing) untuk mengajukan permohonan a quo.

c. Dalil- dalil permohonan para Pemohon beralasan hukum.

Berdasarkan Undang-Undang Dasar Negara Republik Indonesia Tahun 1945 dan mengingat Undang-Undang Nomor 24 Tahun 2003 tentang Mahkamah Konstitusi (Lembaran Negara Republik Indonesia Tahun 2003 Nomor 98, Tambahan Lembaran Negara Republik Indonesia Nomor 4316) dan Undang-Undang Nomor 49 Tahun 2009 tentang Kekuasaan Kehakiman (Lembaran Negara Republik Indonesia Tahun 2009 Nomor 157, Tambahan Lembaran Negara Nomor 5076).

Adapun amar putusannya menyatakan :

a. Menyatakan mengabulkan permohonan para Pemohon untuk seluruhnya.

b. Menyatakan Pasal 34 Undang-Undang Nomor 30 Tahun 2002 tentang Komisi Pemberantasan Tindak Pidana Korupsi (Lembaran Negara Republik Indonesia Tahun 2002 Nomor 137, Tambahan Lembaran Negara Republik Indonesia Nomor 4250) bertentangan dengan Undang-Undang Dasar Negara Republik Indonesia Tahun 1945 sepanjang tidak dimaknai bahwa Pimpinan Komisi Pemberantasan Tindak Pidana Korupsi baik pimpinan yang diangkat secara bersamaan maupun pimpinan pengganti yang diangkat untuk menggantikan pimpinan yang berhenti dalam masa jabatannya memegang jabatan selama 4 (empat) tahun, dan sesudahnya dapat dipilih kembali hanya untuk sekali masa jabatan.

c. Menyatakan Pasal 34 Undang-Undang Nomor 30 Tahun 2002 tentang Komisi Pemberantasan Tindak Pidana Korupsi (Lembaran Negara Republik Indonesia Tahun 2002 Nomor 137, Tambahan Lembaran Negara Republik Indonesia Nomor 4250) tidak mempunyai kekuatan hukum mengikat sepanjang tidak dimaknai bahwa pimpinan Komisi Pemberantasan Tindak Pidana Korupsi baik pimpinan yang diangkat secara bersamaan maupun pimpinan pengganti yang diangkat untuk menggantikan pimpinan yang berhenti dalam masa jabatanya memegang jabatan selama 4 (empat) tahun, dan sesudahnya dapat dipilih kembali hanya untuk sekali masa jabatan.

d. Memerintahkan pemuatan Putusan ini dalam Berita Negara Republik Indonesia sebagaimana mestinya.

Adapun yang menjadi pertimbangan hukum oleh Mahkamah Konstitusi dalam memutus perkara yaitu : Menimbang bahwa menurut Mahkamah, KPK adalah lembaga negara independen yang diberi tugas dan wewenang khusus antara lain melaksanakan sebagian fungsi yang terkait dengan kekuasaan kehakiman untuk melakukan penyelidikan, penyidikan, dan penuntutan serta melakukan supervisi atas penanganan perkara-perkara korupsi yang dilakukan oleh institusi negara yang lain. Untuk mencapai maksud dan tujuan pembentukan KPK sebagai lembaga negara yang khusus memberantas korupsi, maka dalam melaksanakan tugas dan kewenangan secara efektif, KPK dituntut untuk bekerja secara profesional, independen, dan berkesinambungan. Menurut Mahkamah, KPK tidak akan maksimal melaksanakan tugas dan wewenangnya secara profesional dan berkesinambungan tanpa kesinambungan pimpinan KPK. Untuk menjamin kesinambungan tugas-tugas Pimpinan KPK, agar pimpinan tidak secara bersama- sama mulai dari awal lagi, maka penggantian Pimpinan KPK tidak selayaknya diganti serentak. Oleh sebab itu, akan menjadi lebih proporsional dan menjamin kepastian hukum yang adil serta perlakuan yang sama di hadapan hukum apabila terjadi penggantian antarwaktu di antara Pimpinan KPK diangkat untuk satu periode masa jabatan empat tahun [vide Pasal 28D ayat (1) UUD 1945]. ${ }^{36}$

\footnotetext{
${ }^{36}$ Putusan Mahkamah Konstitusi No.5/PUU-IX/2011,hlm.62
} 
Nommensen Journal of Legal Opinion (NJLO)

Jurnal Magister Hukum Program Pascasarjana Universitas HKBP Nommensen

Volume o1 Nomor o1 Juli 2020 Halaman. 01-26

e-ISSN: 2723-164X p-ISSN: 2722-9858

http://ejournal.uhn.ac.id/index.php/opinion

Putusan Mahkamah Konstitusi No. 36//PUU- XV/2017

Putusan Mahkamah Konstitusi No.36/PUU-XV/2007, dalam gugatan uji materi konstitusionalitas Pasal 79 ayat 3 Undang-Undang Nomor 17 Tahun 2014 tentang Majelis Permusyawaratan Rakyat, Dewan Perwakilan Rakyat, Dewan Perwakilan Daerah, dan Dewan Perwakilan Rakyat Daerah terhadap Undang-Undang Dasar Negara Republik Indonesia Tahun 1945. Adapun tiga Pemohon yaitu :

Forum Kajian Hukum dan Konstitusi (FKHK) yang disebut sebagai Pemohon I.

Yudisthira Rifky Darmawan yang disebut sebagai Pemohon II.

Tri Susilo yang disebut sebagai Pemohon III.

Dalam konklusinya berdasarkan penilaian atas fakta dan hukum Mahkamah Konstitusi berkesimpulan bahwa :

a. Mahkamah berwenang mengadili permohonan a quo.

b. Para Pemohon memiliki kedudukan hukum untuk mengajukan permohonan a quo.

c. Permohonan provisi tidak beralasan menurut hukum.

d. Pokok permohonan tidak beralasan menurut hukum.

Berdasarkan Undang-Undang Dasar Negara Republik Indonesia Tahun 1945 dan mengingat Undang-Undang Nomor 24 Tahun 2003 tentang Mahkamah Konstitusi sebagaimana telah diubah dengan Undang-Undang Nomor 8 tahun 2011 tentang Perubahan atas Undang-Undang Nomor 24 tahun 2003 tentang Mahkamah Konstitusi (Lembaran Negara Republik Indonesia Tahun 2011 Nomor 70, Tambahan Lembaran Negara Republik Indonesia Nomor 5226) dan Undang-Undang Nomor 48 Tahun 2009 tentang Kekuasaan Kehakiman (Lembaran Negara Republik Indonesia Tahun 2009 Nomor 157, Tambahan Lembaran Negara Nomor 5076). Berikut Amar putusan Mahkamah Konstitusi menyatakan :

Dalam Provisi : Menolak permohonan provisi para Pemohon.

Dalam Pokok Permohonan : Menolak permohonan para Pemohon.

Adapun yang menjadi pertimbangan hukum oleh Mahkamah Konstitusi yaitu :

Menimbang bahwa dalam perspektif hukum tata negara modern, ada pendapat yang menyatakan banyak lembaga negara yang dibentuk tetapi tidak termasuk dalam suatu cabang kekuasaan, baik legislatif, eksekutif maupun yudikatif (rule making function, rule application function, dan rule adjudication function). Ada lembaga-lembaga penunjang yang menjalankan tugas dan kewenangan di ranah eksekutif akan tetapi dinyatakan sebagai lembaga independen dan tidak berada di bawah kontrol Eksekutif (Presiden). Lantas, bagaimana melihat posisi KPK dalam sistem ketatanegaraan Indonesia? Jika dicermati, dalam Konsiderans menimbang huruf b Undang-Undang No.30 Tahun 2002 Tentang Komisi Pemberantasan Tindak Pidana Korupsi (selanjutnya disebut sebagai UU KPK) dinyatakan : bahwa lembaga pemerintah yang menangani perkara tindak pidana korupsi belum berfungsi secara efektif dan efisien dalam memberantas tindak pidana korupsi. Berpijak dari konsiderans tersebut, yang dimaksud sebagai lembaga pemerintah yang dalam hal ini menangani perkara tindak pidana korupsi ialah Kepolisian dan Kejaksaan. Hal ini dapat diketahui dengan mengingat bahwa tugas penyelidikan, penyidikan atau penuntutan terhadap pelaku tindak pidana korupsi merupakan kewenangan Kepolisian dan Kejaksaan. Dengan demikian, dasar permbentukan KPK ialah karena belum optimalnya lembaga negara in casu Kepolisian dan Kejaksaan yang mengalami public distrust dalam pemberantasan tindak pidana korupsi. Dalam rangka mengembalikan kepercayaan masyarakat terhadap penegakan hukum, dibentuklah KPK. Dalam konstruksi demikian, secara tugas dan fungsi, Kepolisian, Kejaksaan, dan KPK merupakan lembaga yang berada di ranah eksekutif. Bahkan lebih lanjut, tugas utama KPK sebagaimana dinyatakan dalam Pasal 6 ialah melakukan koordinasi dan supervisi terhadap instansi yang berwenang melakukan pemberantasan tindak pidana korupsi, dalam hal ini menjadi trigger mechanism 
bagi Kepolisian dan Kejaksaan. Mengacu pada pendapat Saskia Lavrijssen, 2008, KPK merupakan lembaga penunjang yang terpisah atau bahkan independen, dari departemen eksekutif, akan tetapi sebanarnya "eksekutif". Dalam pandangan Mahkamah, KPK sebenanya merupakan lembaga di ranah eksekutif, yang melaksanakan fungsi-fungsi dalam domain eksekutif, yakni penyelidikan, penyidikan, dan penuntutan. KPK jelas bukan di ranah yudikatif, karena bukan badan pengadilan yang berwenang mengadili dan memutus perkara. KPK juga bukan badan legislatif, karena bukan organ pembentuk Undang-Undang. Benar bahwa KPK merupakan lembaga negara yang dalam melaksanakan tugas dan wewenangnya bersifat independen dan bebas dari pengaruh kekuasaan manapun. Posisinya yang berada di ranah eksekutif, tidak berarti membuat KPK tidak independen dan terbebas dari pengaruh manapun. Dalam putusan Mahkamah Konstitusi Nomor 012-016-019/PUU-IV/2006 pada halaman 269 dinyatakan, independensi dan bebasnya KPK dari pengaruh kekuasaan manapun adalah dalam melaksanakan tugas dan wewenangnya.

Menimbang bahwa oleh karena KPK merupakan lembaga yang berada di ranah eksekutif yang melaksanakan tugas penyelidikan,penyidikan, dan penuntutan dalam perkara tindak pidana korupsi yang sejatinya merupakan kewenangan Kepolisian dan/atau Kejaksaan, bahkan dengan mengingat fungsi KPK sebagai lembaga khusus untuk mendorong agar pemberantasan tindak pidana korupsi dan berjalan secara efektif, efisien , optimal, maka dapat disimpulkan dengan sendirinya bahwa KPK dapat menjadi objek dari hak angket DPR dalam fungsi pengawasannya. Dengan demikian, dalam melaksanakan fungsi pengawasannya, DPR dapat menggunakan hak-hak konstitusionalnya termasuk hak angket terhadap KPK hanya terbatas pada hal-hal yang berkaitan dengan pelaksanaan tugas dan kewenangan KPK selain pelaksanaan tugas dan kewenangan yang berkaitan dengan tugas dan kewenangan yudisialnya (penyelidikan, penyidikan dan penuntutan).

Menimbang bahwa berdasarkan UU KPK, Komisi Pemberantasan Tindak Pidana Korupsi memiliki ruang lingkup tugas, wewenang dan kewajiban yaitu : Pasal 6 UU a quo, KPK mempunyai tugas: (a). Koordinasi dengan instansi yang berwenang untuk melakukan pemberantasan tindak pidana korupsi; (b). Supervisi terhadap instansi yang berwenang melakukan pemberantasan tindak pidana korupsi; (c). Melakukan penyelidikan, penyidikan, dan penuntutan terhadap tindak pidana korupsi; (d). Melakukan tindakan-tindakan pencegahan tindak pidana korupsi; dan (e).Melakukan monitor tehadap penyelenggaraan pemerintahan negara.

Dengan demikian dalam rangka penegakan hukum, Kepolisan, Kejaksaan dan KPK adalah lembaga yang diberikan tugas dan kewenangan untuk melaksanakan undang-undang yang salah satunya adalah pemberantasan tindak pidana korupsi. Meskipun KPK merupakan komisi yang bersifat independen sebagaimana yang diatur dalam UU KPK, namun telah jelas bahwa dalam menjalankan tugas dan kewenangannya sebagaimana institunsi kepolisan dan kejaksaan melaksanakan tugas dan kewenangan pemerintah yang masuk dalam ranah eksekutif.

Menimbang bahwa walaupun dikatakan KPK independen dalam arti bebas dari pengaruh kekuasaan lain, namun DPR sebagai wakil rakyat berhak untuk meminta pertanggungjawaban pelaksanaan tugas dan kewenangan KPK, meskipun KPK juga bertanggung jawab kepada publik, kecuali untuk pelaksanaan tugas dan kewenangan yudisial. Keputusan-keputusan yang diambil oleh KPK dalam melaksanakan tugas dan kewenangannya tidak boleh didasarkan atas pengaruh, arahan maupun tekanan dari pihak manapun termasuk pihak yang berhak meminta pertanggungjawabannya. Bahwa tidaklah dapat dijadikan landasan untuk menyatakan Hak Angket DPR tidak meliputi KPK sebagai lembaga independen, karena secara tekstual jelas bahwa KPK adalah organ atau lembaga yang termasuk 
eksekutif dan pelaksana undang-undang di bidang penegakan hukum khususnya dalam pemberantasan tindak pidana korupsi. ${ }^{37}$

Adapun Kajian Putusan Mahkamah Konstitusi tentang Status dan Kedudukan KPK sebagai Lembaga Negara Independen ialah secara eksplisit kewenangan Mahkamah Konstitusi bertujuan memberi jalan hukum untuk mengatasi perkara dalam hal ini pengujian undangundang yang terkait dengan status dan kedudukan hukum KPK sebagai lembaga negara independen. Dalam mengambil kebijakan atas putusan status dan kedudukan hukum KPK tentu perlu mempertimbangkan dampak atas putusan yang dituangkan salah satunya kepastian hukum. Dalam tulisan Jazim Hamidi mengatakan mengenai teori kepastian hukum, keputusan itu harus ada kepastian, suatu keputusan yang telah dikeluarkan tidak akan dicabut secara semena-mena, karena telah memenuhi persyaratan formil dan materil, asal penerbitan itu bukan karena paksaan atau kelalaian. Suatu kepastian hukum harus dituangkan dalam membuat suatu putusan. Ini merupakan rangka MK dalam menjaga keputusannya sehingga tidak dianggap bentuk dari mereduksi suatu keputusan dengan pertimbangan yang tidak matang atau bisa dibilang memnggunakan pertimbangan yang asal-asalan. Sehingga dalam hal ini MK perlu memperhatikan kembali setiap kebijakan selaku negative legislator demi terwujudnya keberlangsungan sistem Hukum Tata Negara yang berjalan. Tentu MK mengedepankan keadilan subtantif tetapi perlu diperhatikan penjalanan sistem hukum yang akan terlaksana bukan mengedepankan orang yang berperkara di MK tetapi lebih melihat kebutuhan hukum dan harmonisasi warga negara.

Mahkamah Konstitusi dalam mengeluarkan putusan No. 36//PUU-XV/2017 yang berkaitan dengan status dan kedudukan hukum Komisi Pemberantasan Korupsi sebagai lembaga negara independen melalui pertimbangan hukum yang menyatakan bahwa KPK merupakan lembaga yang berada di ranah eksekutif yang melaksanakan tugas penyelidikan, penyidikan, dan penuntutan dalam perkara tindak pidana korupsi yang sejatinya merupakan kewenangan Kepolisian dan/atau Kejaksaan. Meskipun KPK merupakan komisi yang bersifat independent sebagaimana yang diatur dalam UU Nomor 30 tahun 2002 tentang Komisi Pemberantasan Tindak Pidana Korupsi, namun telah jelas bahwa dalam menjalankan tugas dan kewenangannya sebagaimana institusi kepolisian dan kejaksaan melaksanakan tugas dan kewenangan pemerintahan yang masuk dalam ranah eksekutif. Putusan tersebut tidak sejalan jika dibandingkan dengan 4 (empat) putusan MK sebelumnya yaitu putusan No.o12-o16019/PUU-IV/2006, putusan No.19/PUU-V/2007, putusan No.37-39/PUU-VIII/2010, serta putusan No.5/PUU-IX/2011 yang menyatakan bahwa KPK sebagai lembaga negara independen yang tidak masuk ke ranah eksekutif, legislatif, maupun yudikatif . Jika merujuk pada suatu undang-undang , Menurut Mahfud M.D dalam pembuatan sebuah undang- undang, UU yang baru dibentuk bisa menghapus UU yang lama. Namun hal serupa tidak berlaku di pengadilan. Di pengadilan putusan lama itu tidak dapat dihapus dengan putusan yang baru. Yang berlaku itu yang pertama karena sudah inkrah.

Adapun akibat hukum dan kekuatan mengikat Putusan Mahkamah Konstitusi mengenai akibat hukum atas sifat final Putusan MK, sebelumnya sudah ditegaskan pada pasal $24 \mathrm{C}$ Ayat (1) UUD NRI Tahun 1945 yang menyatakan, Mahkamah Konstitusi berwenang mengadili perkara konstitusi dalam tingkat pertama dan terakhir yang putusannya bersifat final. Ketentuan tersebut kemudian diatur lebih lanjut ke dalam Pasal 10 ayat (1) Undang-Undang No.23 Tahun 2003 tentang Mahkamah Konstitusi. Pasal 47 UU MK, Mahkamah Konstitusi mempertegas sifat final tersebut dengan menyatakan bahwa Putusan MK memperoleh kekuatan hukum tetap sejak diucapkan dalam sidang pleno yang terbuka untuk umum.

Berdasarkan ketentuan tersebut, sifat final menunjukkan setidaknya 3 (tiga) hal, yaitu :

${ }^{37}$ Putusan Mahkamah Konstitusi No.36/PUU-XV/2017,hlm.109 
(1) Bahwa putusan MK secara langsung memperoleh kekuatan hukum;

(2) Karena telah memperoleh kekuatan hukum maka Putusan MK memiliki akibat hukum bagi semua pihak yang berkaitan dengan putusan. Hal ini karena putusan MK berbeda dengan putusan peradilan umum yang hanya mengikat para pihak berperkara (interparties). Semua pihak wajib mematuhi dan melaksanakan Putusan MK. Dalam Putusan MK terkait dengan pengujian undang-undang (PUU) misalnya, jika MK memutus suatu UU bertentangan dengan UUD dan menyatakannya tidak memiliki kekuatan mengikat maka putusan tersebut tidak hanya mengikat bagi para pihak yang mengajukan perkara di MK, melainkan mengikat juga semua warga negara seperti halnya UU mengikat secara umum bagi semua warga negara. Atas dasar itu, maka putusan MK bersifat erga omnes,

(3) Karena merupakan pengadilan pertama dan terakhir, maka tidak ada upaya hukum lain yang dapat ditempuh. Sebuah putusan apabila tidak ada upaya hukum yang dapat ditempuh berarti telah mempunyai kekuatan hukum tetap (in kracht van gewijsde) dan memperoleh kekuatan mengikat (resjudicata pro veritate habetur). Dalam kaitannya jika suatu permohonan pengujian undang-undang dikabulkan oleh MK, maka tindak lanjut sebagai konsekuensinya, peraturan berupa undang-undang itu akan dirubah sebagian, ataupun keseluruhannya, oleh pihak pembuat undang-undang.

Jika MK menolak permohonan pengujian undang-undang, maka siapapun tidak boleh mengajukan permohonan pengujian undang-undang baik segi pembuatannnya ataupun segi materi muatannya (substansi materinya) dari undang-undang yang sama, yang pernah diuji dan diputus oleh MK tersebut. Jika permohonan tidak dapat diterima maka masih terbuka kemungkinan bagi para pihak lain untuk mengajukan permohonan pengujian yang sama. Pihak lain yang dimaksud adalah orang, kelompok atau badan hukum (natuurlijkeperson dan rechtpersoon) yang dinilai memenuhi persyaratan legal standing sebagai pemohon serta mampu menunjukkan kerugian konstitusionalnya sebgai diatur dalam Pasal 51 undang-undang No.24 tahun 2003 tentang Mahkamah Konstitusi dan yuriprudensi. Pengujian undang-undang yang menjadi kewenangan MK adalah menguji secara konstitusionalitas suatu undang-undang, menguji sejauh mana undnag-undang yang bersangkutan bersesuai atau bertentangan (tegengsteld) dengan UUD. Constitutie is de hoogste wet, kata Laica Marzuki. Manakala Mahkamah Konstitusi memang suatu undang-undang bertentangan dengan UUD, maka undang-undang tersebut tidak mempunyai kekuatan hukum mengikat.

Mahkamah Konstitusi tidak membatallkan keberlakuan suatu undang-undang tetapi menyatakan bahwasanya suatu undang-undang, atau materi ayat, pasal dan/atau bagian undang-undang tidak lagi mempunyai kekuatan hukum mengikat (not legally binding). Mahkamah tidaklah dapat mengubah rumusan redaksi, ayat, pasal dan/atau bagian undangundang. Uraian tersebut menandakan bahwasanya MK tidak berwenang mengganti atau memasukkan norma baru ke dalam materi muatan ( ayat, pasal dan/atau bagian) UU yang telah dinyatakan bertentangan dengan UUD 1945 sehingga tidak mempunyai kekuatan hukum mengikat. Pernah ditegaskan oleh Jimly Asshiddiqie pada saat menjabat sebagai Ketua Mahkmah Konstitusi , bahwasanya posisi MK adalah sebagai negative legislator yang artinya, MK hanya bisa memutus sebuah norma dalam UU bertentangan konstitusi, tanpa boleh memasukan norma baru ke dalam UU.

\section{Inkonsisten Putusan Mahkamah Konstitusi dalam Menentukan Status dan Kedudukan Hukum KPK Melalui Putusan No.36/PUU-XV/2017}

Mahkamah Konstitusi dalam menjalankan kewenangannya mengeluarkan sebuah putusan yang dianggap merusak kebijakannya sendiri dalam melakukan judical review atas putusannya yang dianggap gagal dalam mengawal konsistensi putusan. Menurut hemat saya, 
Mahkamah tidak "Konsisten" dalam mengambil kebijakan yang seharusnya menjadi acuan kedepan tetapi dapat berubah dan menimbulkan ketidakpastian dalam hukum. Ini dianggap Mahkamah Konstitusi tidak menghormati pembentuk Undang-Undang dan tergesa-gesa dalam menuangkan ke dalam suatu putusan.

Dengan adanya putusan No. 012-016-019/PUU-IV/2006, No. 19/PUU-V/2007, No. 3739/PUU-VIII/2010, No. 5/PUU/IX/2011 yang dieliminasi dengan munculnya Putusan No.36/PUU-XV/2017 tentu menimbulkan benturan hukum serta ketidakkonsisten ketika adanya satu putusan terbaru yang berbeda dengan empat putusan sebelumnya dengan substansi yang sama. Mengingat sebelumnya Mahkamah Konstitusi memiliki kewenangan menguji UU terhadap UUD 1945 sebagai satu-satunya lembaga peradilan yang memiliki kewenangan sebagai penafsir konstitusi tetapi kemudian dengan munculnya ketidakkonsistenan putusan terbaru dengan empat putusan sebelumnya dalam menentukan status dan kedudukan KPK sebagai lembaga negara independen. Tentu hal tersebut mensyaratkan Mahkamah Konstitusi gagal mengawal konsistensi putusannya dalam menjaga serta mewujudkan kepastian hukum, mengingat kepastian hukum merupakan faktor penting dalam menjaga kepercayaan kepada institusi lembaga peradilan tersebut. Hal tersebut dapat dilihat dengan dikeluarkan dan berlakunya putusan No. 36/PUU-XV/2017, yang didalam pertimbangan hukum Mahkamah berpendapat bahwa status dan kedudukan hukum KPK merupakan sebagai lembaga negara yang berada di ranah eksekutif, jika dilihat faktanya bahwa terjadi inkonsisten terhadap 4 (empat) putusan sebelumnya yang menyatakan KPK sebagai lembaga negara independen, tidak berada di ruang lingkup eksekutif, legislatif ,maupun yudikatif.

Adapun pertimbangan hukum oleh Mahkamah Konstitusi dalam mengeluarkan putusan No. 36/PUU-XV/2017 yaitu : Pertama (1) Dalam pandangan Mahkamah, KPK sebenanya merupakan lembaga di ranah eksekutif, yang melaksanakan fungsi-fungsi dalam domain eksekutif, yakni penyelidikan, penyidikan, dan penuntutan. KPK jelas bukan di ranah yudikatif, karena bukan badan pengadilan yang berwenang mengadili dan memutus perkara. KPK juga bukan badan legislatif, karena bukan organ pembentuk Undang-Undang. Kedua (2) KPK merupakan lembaga yang berada di ranah eksekutif yang melaksanakan tugas penyelidikan, penyidikan, dan penuntutan dalam perkara tindak pidana korupsi yang sejatinya merupakan kewenangan Kepolisian dan/atau Kejaksaan, bahkan dengan mengingat fungsi KPK sebagai lembaga khusus untuk mendorong agar pemberantasan tindak pidana korupsi dan berjalan secara efektif, efisien, optimal, maka dapat disimpulkan dengan sendirinya bahwa KPK dapat menjadi objek dari hak angket DPR dalam fungsi pengawasannya. Dengan demikian, dalam melaksanakan fungsi pengawasannya, DPR dapat menggunakan hak-hak konstitusionalnya termasuk hak angket terhadap KPK hanya terbatas pada hal-hal yang berkaitan dengan pelaksanaan tugas dan kewenangan KPK selain pelaksanaan tugas dan kewenangan yang berkaitan dengan tugas dan kewenangan yudisialnya (penyelidikan, penyidikan dan penuntutan).

Dengan demikian berlakunya status dan kedudukam hukum KPK sebagai lembaga negara yang berada di ranah eksekutif bukan hanya tidak sejalan dengan 4 (empat) putusan MK sebelumnya tatapi bahkan tidak sejalan dengan bunyi Pasal 1 ayat (3) UU No 30 tahun 2002 yang menyatakan "Komisi Pemberantasan Korupsi adalah lembaga negara yang dalam melaksanakan tugas dan wewenangnya bersifat independen dan bebas dari pengaruh kekuasaan manapun. Namun perlu juga disinggung dalam memutuskan perkara No. 36/PUU$\mathrm{XV} / 2017$ terdapat perbedaan pendapat (dissenting opinion) oleh empat hakim Mahkamah Konstitusi yaitu : Hakim Konstitusi Maria Farida Indrati, Hakim Konstitusi I Dewa Gede Palguna, Hakim Suhartoyo, dan Hakim Konsitusi Saldi Isra bahwa tanpa hendak bernaksud 
menagitkan dengan kasusu konkret, pemahaman komprehensif dalam menjelaskan frasa "penyelidikan terhadap pelaksanaan suatu UU dan/atau kebijakan Pemerintah", seperti yang diatur dalam norma Pasal 79 ayat (3) UU MD3 tersebut, hal pokok yang harus dijelaskan adalah bagaimana sesungguhnya secara teoritis membuat perbedaan antara lembaga negara yang secara tradisional dibedakan menjadi tiga cabang kekuasaan dalam doktrin trias politika (yaitu: eksekutif, legislatif dan yudikatif) dengan lembaga yang disematkan status "independen" dalam perkembangan teori hukum tata negara modern ( modern constitutional law theory).

Terkait dengan hal ini Asimow dalam bukunya Administrative law (2002) menyatakan unit of government created by statute to carry out specific task in implementing the statue. Most administrative agencies fall in the executive branch, but some important agencies are independent. Organ negara ( state organ) yang disematkan status independen karenanya berada di luar ketiga cabang kekuasaan dalam doktrin trias politika tersebut. Dalam hal ini, William F. Funk \& Richard. H Seamon mengatakan bahwa lembaga yang disebut dengan independen itu tidak jarang memiliki kekuasaan "quasi legislative", "quasi executive", dan "quasi judical". Sejalan dengan pendapat tersebut, Jimly Asshiddiqie (2006) menyebutkan organ negara independen karena berada di luar cabang kekuasaan eksekutif, legislatif, dan yudikatif. Artinya ,dengan penyematan posisi “quasi” tersebut, lembaga independen tidak termasuk dalam cabang kekuasaan legislatif, eksekutif maupun yudikatif.

Selanjutnya, mengikuti perkembangan dalam teori hukum tata negara, sebuah lembaga dikatakan independen, apabila :

a. Posisi Independen tersebut dinyatakan secara tegas (eksplisit) dalam dasar hukum pembentukannya, baik yang diatur dalam konstitusi atau diatur dalam undang- undang.

b. Pengisian pimpinan lembaga bersangkutan tidak dilakukan oleh satu lembaga saja.

c. Pemberhentian anggota lembaga independen hanya dapat dilakukan berdasarkan oleh sebab-sebab yang diatur dalam undang-undang yang menjadi dasar pembentukan lembaga yang bersangkutan.

d. Presiden dibatasi untuk tidak bebas memutuskan (discretionary decision) pemberhentian pimpinan lembaga negara independen.

e. Pimpinan bersifat kolektif dan masa jabatan para pemimpin tidak habis secara bersamaan, tetapi bergantung (staggered terems).

Bahwa apabila pandangan teoretik tersebut dikaitkan dengan posisi KPK dalam sistem ketatanegaraan Indonesia, semua elemen lembaga negara independen dipenuhi dalam UU No.3o tahun 2002 tentang Komisi Pemberantasan Tindak Pidana Korupsi (UU KPK). Secara hukum, serangkain putusan MK telah berulangkali menyatakan independensi posis KPK, di antaranya : (1) Putusan Mahkamah Konstitusi Nomor o12-016-019/PUU-IV/2006, tetanggal 19 Desember 2006; (2) Putusan Mahkamah Konstusi Nomor 19/PUU-V/2007, tertanggal 13 November 2007; (3) Putusan Mahkamah Konstitusi Nomor 37-37/PUU-VIII/2010 tertanggal 15 Oktober 2010; (4) Putusan Mahkamah Konstitusi Nomor 5/PUU-IX/2011, tertanggal 20 Juni 2011. Independensi posisi KPK dalam sistem ketatanegaraan Indonesia masih dapat ditelisik dari belasan putusan Mahkamah Konstitusi yang lain. Secara umum, serangkain putusan Mahkamah Konstitusi tersebut menegaskan;

a. Pembentukan lembaga seperti KPK dapat dianngap penting secara konstitusional (constitutionally important) dan keberadaan komisi-komisi negara semacam KPK telah merupakan suatu hal yang lazim.

b. Sifat kelembagaan KPK adalah sebagai lembaga penegakan hukum dalam bidang tindak pidana korupsi.

c. KPK merupakan lembaga negara yang bersifat independen yang dalam melaksanakan tugas dan wewenangnya bebas dari campur (campur-tangan) kekuasaan manapun. 
d. KPK adalah lembaga negara independen yang diberi tugas dan wewenang khusus antara lain melaksanakan sebagai fungsi yang terkait dengan kekuasaan kehakiman untuk melakukan penyelidikan, penyidikan, dan penuntutan serta melakukan supervisi atas penanganan perkara-perkara korupsi yang dilakukan oleh institusi negara lain.

e. Pimpinan bersifat kolektif dan berakhirnya masa jabatan pimpinan (dapat) habis secara bergantian (staggered terms).

Bahwa teori hukum tata negara dan rekaman putusan Mahkamah Konstitusi di atas telah menjadi benteng yang kokoh dalam mempertahankan dan meneguhkan posisi KPK dalam desain besar (grand design) agenda pemberantasan korupsi sebagai salah satu amanah pokok yang diperjuangkan pada Era Reformasi serta mengaskan bahwa KPK merupakan lembaga independen yang bukan berada di dalam tiga cabang lembaga kekuasaan negara di dalam doktrin trias politika. Dengan demikian, telah jelas bahwa KPK bukan termasuk dalam cabang kekuasaan eksekutif. Penegasan demikian menjadi semacam keniscayaan karena sejak awal terbentuknya, terutama sejak KPK mampu membuktikan diri sebagai lembaga pemberantasan tindak pidana korupsi yang mampu dan berani menyentuh semua lembaga negara yang merupakan episentrun kekuasaan negara, serta pejabat negara (di pusat maupun daerah) mulai dikembangkannya pandangan/pendapat bahwa KPK merupakan lembaga yang dibentuk untuk sementara waktu (ad-hoc). Dari berbagai perspektif, pandangan demikian sangat lemah. Pertama, secara hukum tidak ditemukan satupun kalimat termausk frasa dalam UU KPK yang menyebutkan bahwa KPK sebagai lembaga ad hoc. Kedua, apabila dibaca United Convention Againts Corruption (UNCAC), setiap negara peserta (state party) dibebani kewajiban untuk membentuk lembaga khusus dalam memberantas tindak pidana korupsi. Kalaupun dimaknai ad-hoc maka pemaknaan tersebut adalah dalam pengertian lembaga yang dibentuk secara khusus sesuai dengan semangat UCAC. Bahkan semangat yang sama jauh-jauh hari sebelumnya telah menjadi roh Ketetapan MPR Nomor XI/MPR/1998 tentang Penyelenggara Negara Yang Besih dan Bebas Korupsi, Kolusi dan Nepotisme (KKN) dan diikuti dengan Ketetapan MPR No VIII/MPR/2001 tentang Rekomendasi Arah Kebijakan Pemberantasan dan Pencegahan KKN. Ketiga, pengalaman Hongkong, Thailand, China dan Malaysia yang juga berupaya keluar dari ancaman dan jebakan perilaku koruptif sama sekali tidak memosisikan komisi seperti KPK sebagai lembaga ad-hoc dalam pengertian hanya untuk sementara waktu. Bahkan, begitu pentingnya pembentukan sebuah lembaga atau komisi khusus dalam memberantas korupsi, misalnya,negara seperti Thailand meningkatkan status dasar hukum pengaturan lembaga semacam KPK hingga menempatkannya menjadi lembaga yang diatur dalam konstitusi. Buktinya Pasal 247-251 Konstitusi Thailand 2007 mengatur eksistensi dari komisi Independen The National Counter Corruption Commision.

Sementara itu, terhadap pertimbangan tersebut diatas, Hakim Konstitusi Maria Farida Indrati ${ }^{38}$ mempunyai alasan berbeda terhadap posisi KPK dalam sistem ketatanegaraan Indonesia, yaitu sebagai berikut: KPK adalah lembaga yang terbentuk berdasarkan Ketetapan MPR Nomor XI/MPR/1998 tentang Penyelenggara Negara Yang Bersih dan Bebas Korupsi, Kolusi, dan Nepotisme, yang mengatur antara lain, perlunya dibentuk suatu lembaga oleh Kepala Negara yang keanggotaannya terdiri atas Pemerintah dan masyarakat, sebagai upaya pemberantasan tindak pidana korupsi yang dilakukan secara tegas dengan melaksanakan secara konsisten undang- undang tindak pidana korupsi [Vide Pasal 3 ayat (2) dan ayat (3)]. Selain itu, untuk mempercepat dan menjamin efektivitas pemberantasan korupsi, kolusi, dan nepotisme tersebut dibentuklah Ketetapan MPR Nomor VIII/MPR/2001 tentang Rekomendasi Arah Kebijakan Pemberantasan dan Pencegahan Korupsi, Kolusi, dan Nepotisme.

${ }^{38}$ Maria Farida, Dissenting Opinion, Putusan Mahkamah Konstitusi No.36/PUU-XV/2017,hlm.127 
Sebagai tindak lanjut dari kedua Ketetapan MPR tersebut maka dibentuklah UU Nomor 31 tahun 1999 tentang Pemberantasan Tindak Pidana Korupsi yang kemudian diubah dengan UU Nomor 20 tahun 2001 tentang Perubahan atas UU Nomor 31 tahun 1999 tentang Pemberantasan Tindak Pidana Korupsi, yang mengamanatkan perlunya dibentuk KPK yang independen dengan tugas dan wewenang melakukan tindak pidana korupsi. Berdasarkan kedua undang-undang tersebut dibentuklah UU No 30 tahun 2002 tentang Komisi Pemberantasan Tindak Pidana Korupsi, yang dalam konsiderans Menimbang huruf b menyatakan "bahwa lembaga pemerintah yang menangani perkara tindak pidana korupsi belum berfungsi secara efektif dan efisien dalam memberantas tindak pidana korupsi”. Berdasarkan pertimbangan tersebut diatas dapat dikemukakan bahwa KPK adalah termasuk dalam ranah kekuasaan eksekutif yang sering disebut lembaga pemerintah walaupun mempunyai ciri independen. Independen disini harus dimaknai independen dalam melaksanakan tugas dan kewenangannya.

Berdasarkan pertimbangan hukum Mahkamah Konstitusi serta pendapat hakim konstitusi yang secara eksplisit telah tercantum dalam putusan No.36/PUU-XV/2017 mengenai status dan kedudukan hukum Komisi Pemberantasan Korupsi dapat disimpulkan bahwa Komisi Pemberantasan Korupsi merupakan lembaga negara yang berada di bawah ranah eksekutif. Artinya bahwa keberadaan KPK sama seperti Kejaksaan dan Kepolisian. Jika kita melihat dari latar belakang terbentuknya KPK , bahwa KPK dibentuk karena tidak maksimalnya lembaga Kejaksaan dan Kepolisian dalam menangani tindak pidana korupsi sehingga diperlukan lembaga independen khusus yang menangani korupsi di Indonesia. Dengan dikeluarkannya putusan tersebut kita dapat melihat bahwa dalam menentukan status dan kedudukan hukum KPK adanya perbandingan 5:4 oleh hakim MK, dimana lima hakim MK menyetujui serta sepakat bahwa KPK merupakan lembaga di bawah ranah eksekutif sedangkan empat hakim tetap menyatakan bahwa KPK merupakan lembaga independen , yang tidak berada di ranah eksekutif, legislatif maupun yudikatif. Hal tersebut dapat dilihat dari "disenting opinion" hakim MK dalam putusan tersebut.

\section{D.Kesimpulan}

Berdasarkan pembahasan atas bab sebelumnya maka penulisan memiliki kesimpulan antara lain, pertama, Pertimbangan Mahkamah Konstitusi dalam memutus perkara No.o12016-019/PUU-IV/2006, No.19/PUU-V/2017, No.37-39/PUU-VIII/2010, No.5/PUU-IX/2011 adalah bahwa Komisi Pemberantasan Korupsi adalah lembaga negara yang dalam melaksanakan tugas dan wewenangnya bersifat independen dan bebas dari pengaruh kekuasaan mana pun. Mahkamah berpendapat bahwa penegasan tentang independensi dan bebasnya KPK dari pengaruh kekuasaan mana pun dalam melaksanakan tugas dan wewenangnya justru menjadi penting agar tidak terdapat keragu-raguan dalam diri pejabat KPK untuk melaksanakan tugas dan kewajibannya untuk memberantas korupsi. Adapun pertimbangan Mahkamah Konstitusi dalam memutus perkara No.36/PUU-XV/2017 adalah bahwa KPK merupakan lembaga yang berada di ranah eksekutif yang melaksanakan tugas penyelidikan,penyidikan, dan penuntutan dalam perkara tindak pidana korupsi yang sejatinya merupakan kewenangan Kepolisian dan/atau Kejaksaan, bahkan dengan mengingat fungsi KPK sebagai lembaga khusus untuk mendorong agar pemberantasan tindak pidana korupsi dan berjalan secara efektif, efisien , optimal. Dapat dilihat dari pertimbangan hukum Mahkamah Konstitusi diatas bahwa putusan No.012-016-019/PUU-IV/2006, No.19/PUU-V/2017, No.37-39/PUU-VIII/2010, No.5/PUU-IX/2011 tidak sejalan dengan Putusan No. No.36/PUU-XV/2017. Kedua, Mahkamah Konstitusi inkonsistensi dalam menentukan status dan kedudukan hukum Komisi Pemberantasan Korupsi melalui putusannya karena KPK sebenarnya merupakan lembaga di ranah eksekutif, 
yang melaksanakan fungsi-fungsi dalam domain eksekutif, yakni penyelidikan, penyidikan, dan penuntutan. KPK jelas bukan di ranah yudikatif, karena bukan badan pengadilan yang berwenang mengadili dan memutus perkara. KPK juga bukan badan legislatif, karena bukan organ pembentuk Undang-Undang. Benar bahwa KPK merupakan lembaga negara yang dalam melaksanakan tugas dan wewenangnya bersifat independen dan bebas dari pengaruh kekuasaan manapun. Posisinya yang berada di ranah eksekutif, tidak berarti membuat KPK tidak independen dan terbebas dari pengaruh manapun.

Mahkamah Konstitusi sebagai Lembaga Negara yang merdeka dengan mempunyai kewenangan yang luas perlu mempertimbangkan kebijakan hukum yang akan dipilih dan dimuat dalam suatu putusan dengan dasar hukum hakim yang digunakan, mengingat suatu putusan tersebut akan berdampak pada semua peraturan perundang-undangan yang berlaku. Sehingga kepastian hukum akan terjamin jika MK memilih untuk mengedepankan keadilan subtantif. Pengambilan suatu putusan seyogyanya, menggunakan pertimbangan hukum yang matang dengan melihat kebutuhan hukum dan dapat menghindari pengambilan kebijakan yang berdampak luas. Mengingat Mahkamah Konstitusi sebagai Negative Legislator tentu Mahkamah Konstitusi berwenang hanya dalam menafsirkan norma-norma yang bertentangan dengan UUD tanpa perlu menjatuhkan suatu kebijakan baru yang seharusnya menjadi kewenangan pembentuk UU.

\section{Daftar Pustaka}

Black's Law, Judical review diartikan sebagai:power of courts to review decisions of another departmen or level of government."Henry Campbell Black.Black's Law Dictionary with Pronunciations.6 th ed. ( United States of America: West Publishing Co,1990).

Cetak biru, Membangun Mahkamah Konstitusi, Sebagai Institusi Peradilan Konstitusi yang Modern dan Terpercaya, Seketariat Jendral MKRI,2004.

David P.Currie,The Constitution of the United States, A Prime for the people,Chicago dan Landon,The University of the Chicago Press,1998,hlm.14 dan Lawrence M.Friedman, America Law an Introduction,second edition,terjemahan wisnu basuki dalam buku Taufiqurahman Syahuri, Tafsir Konstitusi berbagai Aspek Hukum, Jakarta: Kencana,2oo1.

Hans Kelsen, General Theory of Law and State, Translated by Anders Wedberg, New York: Russel dan Russel, 1961.

Herbert Hausmaininger, The Austrian Legal Sistem,Wien,2003,hlm.139 dalam Jimly Asshiddiqie, Model-model Pengujian Konstitusional di berbagai Negara ,Jakarta : Sinar Grafika,2010, ( selanjutnya disingkat Jimly Asshiddiqie I)

Simamora, Janpatar., Tafsir Makna Negara Hukum dalam Perspektif Undang-Undang Dasar Negara Republik Indonesia Tahun 1945, Jurnal Dinamika Hukum FH Universitas Jenderal Soedirman, Vol. 14 No. 3 September 2014.

Simamora, Janpatar., Analisa Yuridis Terhadap Model Kewenangan Judicial Review di Indonesia, Jurnal Mimbar Hukum FH Universitas Gadjah Mada Yogyakarta, Vol. 25 No. 3 Oktober 2013.

Simamora, Janpatar., Problematika Penyelesaian Sangketa Kewenangan Lembaga Negara oleh Mahkamah Konstitusi, Jurnal Mimbar Hukum FH UGM Yogyakarta, Volume 28, Nomor 1, Februari 2016.

Simamora, Janpatar. Development of Constitutional Interpretation by Constitutional Court of Indonesia in the Context of State Institutions' Authority Dispute Settlement, IOSR Journal Of Humanities And Social Science (IOSR-JHSS) Vol 24 Issue 12, Series. 3 December 2019: 45-54. 
Simamora, Janpatar, and Haposan Siallagan. "Hans Kelsen's Thoughts On The Authority Model Of The Constitutional Of Indonesia." Journal of Talent Development and Excellence 12, No. 1 (2020): 4411-4415.

Sara Tambun, Goncalwes Sirait, Janpatar Simamora, Analisis Yuridis Hak dan Kewajiban Warga Negara Menurut Undang-Undang Nomor 20 Tahun 2003 tentang Sistem Pendidikan Nasional, Jurnal Visi Ilmu Sosial Humaniora, Vol. 1 No. o1 Juni 2020.

Simamora, Janpatar dan Naibaho, Bintang ME., Statutory of The Republic of Indonesia Witness As a Government Institution Implementing Country's Power in The Indonesian State Concerns System, Proceedings of the First Nommensen International Conference on Creativity \& Technology, NICCT, 20-21 September 2019, Medan, North Sumatera, Indonesia.

Simamora, Janpatar., Kepastian Hukum Pengajuan Kasasi oleh Jaksa Penuntut Umum Terhadap Vonis Bebas, Jurnal Yudisial, Komisi Yudisial RI, Volume 7 Nomor 1 April 2014, page $1-17$.

Jimly Asshiddiqie, Gagasan Negara Hukum Indonesia, Jakarta: Majalah Hukum Indonesia, 2005. Jimly Asshiddiqie dalam Pengantar Mahkamah Konstitusi Komplikasi Konstitusi UndangUndang dan Peraturan di 78 negara, Pusat Studi Hukum Tata Negara, Universitas Indonesia,2003.

Miftakhul Huda, Ultra Petita dalam Pengujian Undang-Undang,dalam Jurnal Konstitusi Volume 4 Nomor 3 September 2007.

Mariyadi Faqih,Nilai-Nilai Filosofi Putusan Mahkamah Konstitusi yang final dan Mengikat, dalam Jurnal Konstitusi Volume 7 Nomor 3 Juni 2010, Sekretarian Jendral dan Kepaniteraan Mahkamah Konstitusi,Jakarta.

Peter Mahmud Marzuki, Penelitian Hukum, Kencana Prenamedia Group,Jakarta,2007.

Padmo Wahjono,Indonesia Negara Berdasarkan Atas Hukum, Cetakan 2, Jakarta, Ghalia Indonesia,1986.

Ronal Dworkin, Taking Rights Seriously,Cambridge,Massachusetts: Harvard University Press, 1978.

Soerjono Soekanto dan Srimamudji, Panel Hukum Normatif, Jakarta: Raja Grafindo Persada, 2014.

Sekretariat Jendral dan Kepaniteraan Mahkamah Konstitusi Republik Indonesia, Hukum Acara Mahkamah Konstitusi, Jakarta : Cetakan Pertama Agustus, 2010.

Putusan Mahkamah Konstitusi No.012-016-019/PUU-IV/2006.

Putusan Mahkamah Konstitusi No.19/PUU-V/2007.

Putusan Mahkamah Konstitusi No.37-39/PUU-VIII/2010.

Putusan Mahkamah Konstitusi No.5/PUU-IX/2011.

Putusan Mahkamah Konstitusi No.36/PUU-XV/2017. 